\title{
In situ fluxes and zonation of microbial activity in surface sediments of the Håkon Mosby Mud Volcano
}

\author{
Dirk de Beer ${ }^{1}$
}

Max-Planck-Institute for Marine Microbiology, Celsiusstrasse 1, 28359 Bremen, Germany

Eberhard Sauter

Alfred-Wegener-Institute for Polar and Marine Research, Columbusstrasse, 27568 Bremerhaven, Germany

\section{Helge Niemann}

Max-Planck-Institute for Marine Microbiology, Celsiusstrasse 1, 28359 Bremen, Germany

\section{Norbert Kaul}

Department of Geosciences, University of Bremen, Klagenfurtherstrasse, 28359 Bremen, Germany

\section{Jean-Paul Foucher}

Marine Geosciences, IFREMER Centre de Brest, BP70, 29280 Plouzane, France

\section{Ursula Witte}

Max-Planck-Institute for Marine Microbiology, Celsiusstrasse 1, 28359 Bremen, Germany

\section{Michael Schlüter}

Alfred-Wegener-Institute for Polar and Marine Research, Columbusstrasse, 27568 Bremerhaven, Germany

\section{Antje Boetius}

Max-Planck-Institute for Marine Microbiology, Celsiusstrasse 1, 28359 Bremen, Germany

\begin{abstract}
From the Håkon Mosby Mud Volcano (HMMV) on the southwest Barents Sea shelf, gas and fluids are expelled by active mud volcanism. We studied the mass transfer phenomena and microbial conversions in the surface layers using in situ microsensor measurements and on retrieved cores. The HMMV consists of three concentric habitats: a central area with gray mud, a surrounding area covered by white mats of big sulfide oxidizing filamentous bacteria (Beggiatoa), and a peripheral area colonized by symbiontic tube worms (Pogonophora). A fourth habitat comprised gray microbial mats near gas seeps. The differences between these four methane-fueled habitats are best explained by different transport rates of sulfate into the sediments and porewater upflow rates. The upflow velocities were estimated by two independent methods at $3-6 \mathrm{~m} \mathrm{yr}^{-1}$ in the central area and $0.3-1 \mathrm{~m} \mathrm{yr}^{-1}$ in Beggiatoa mats. In the central area no sulfide was found, indicating that the rapidly rising sulfate-free fluids caused sulfate limitation that inhibited anaerobic oxidation of methane (AOM). Under Beggiatoa mats a steep sulfide peak was found at 2 to $3 \mathrm{~cm}$ below the seafloor (bsf), most likely due to AOM. All sulfide was oxidized anaerobically, possibly through nitrate reduction by Beggiatoa. The Beggiatoa mats were dominated by a single filamentous morphotype with a diameter of $10 \mu \mathrm{m}$ and abundant sulfur inclusions. A high diversity of sulfide oxidizer morphotypes was observed in a grayish microbial mat near gas vents, where aerobic sulfide oxidation was important. The sediments colonized by Pogonophora were influenced by bioventilation, allowing sulfate penetration and AOM to $70 \mathrm{~cm}$ bsf. The HMMV is a unique and diverse ecosystem, the structure and functioning of which is mainly controlled by pore-water flow.
\end{abstract}

Interest in anaerobic oxidation of methane (AOM) and its linkage to sulfate reduction was strongly stimulated by the recent discovery of the microorganisms involved (Boetius et al. 2000; Michaelis et al. 2002; Orphan et al. 2002). Evidence was presented that consortia of methano-

\footnotetext{
${ }^{1}$ Corresponding author (dbeer@mpi-bremen.de).
}

trophic archaea and sulfate-reducing bacteria are responsible for the process. These microorganisms were found in high abundance in methane-rich sediments above gas hydrates and various types of cold seeps. The microbial conversion of methane and sulfate to $\mathrm{CO}_{2}$ and sulfide in surface sediments is usually accompanied by sulfide oxidation (SO) by free-living and symbiotic bacteria. 
Sediments with high methane fluxes and high rates of AOM are typically covered with white mats of sulfide-oxidizing filamentous bacteria. These sulfide oxidizers are members of a distinct phylogenetic group, comprising giant bacteria such as Beggiatoa, Thioploca, and Thiomargarita. The larger species of this group can store large amounts of nitrate inside their vacuoles for use in anoxic and nitratefree deeper sediment layers (Schulz and Jørgensen 2001). The combination of both AOM and SO shields the ocean water and the atmosphere from release of methane and sulfide from the sediments. This has great ecological significance, because methane is a powerful greenhouse gas when released into the atmosphere and because sulfide is highly toxic for many organisms. We investigated the efficiency of this biofilter and the controlling factors of the respective microbial processes using the first high-resolution, in situ biogeochemical study of a cold seep. Despite intensive efforts, the microbes involved in methane oxidation processes have not been isolated; thus, the precise pathways and controlling factors are still unknown. Most critically, the actual oxidation rates have not yet been determined in situ. Retrieval of methane-rich sediments generally results in strong disturbance during sample recovery by degassing. Rate measurements on such disturbed sediments are bound to be incorrect. Hence, the actual environmental settings and biogeochemical effects of $\mathrm{AOM}$ and $\mathrm{SO}$ associated with methane hydrates and strongly gaseous cold seeps are not known.

Benthic microbial activity is limited by kinetics (availability of suitable microbes, $\mathrm{pH}$, temperature $(\mathrm{T})$, and other microenvironmental factors) or by mass transfer rates (availability of reactants). Since advectional exchange between seawater and sediment is hindered, mass transfer of substrates to the cells most commonly limits turnover rates. Because of the mass transfer resistance, steep profiles of substrates and products develop. These profiles are best measured by microsensors, small needle-shaped probes with a tip diameter of $1-20 \mu \mathrm{m}$ that minimally disturb sediments or microenvironments (Revsbech and Jørgensen 1986; Kühl and Revsbech 2000; Gieseke et al. 2003). As the profiles of reactants are determined by microbial conversion rates and mass transport resistance, microbial conversion rates can be calculated from the measured

\footnotetext{
Acknowledgments

We are grateful for the technical assistance with the deployments by Gaby Eickert, Anne-Katrin Schlesier, and Axel Nordhausen, as well as for the superb microsensors from Gaby Eickert, Ines Schröder, Vera Hübner, Karin Hohmann, and Cecilia Wiegand. We thank Lubos Polerecky for solving the differential equation and Bo Barker Jørgensen, Dieter WolfGladrow, and Jonathan Erez for theoretical assistance. The team from GENAVIR/IFREMER is acknowledged for the expert operations with ROV 'Victor'. We thank the crew and officers of the RV Polarstern for their excellent support. We thank Klaus Wallmann and two anonymous reviewers for their constructive critiques of the manuscript.

The study was funded by the Bundesministerium für Bildung und Forschung and the Deutsche Forschungsgemeinschaft in the frame of the GEOTECHNOLOGIEN project MUMM (FKZ G0554A, 03G0608A).
}

profiles when the mass transfer rates are quantified (Berg et al. 1998; De Beer and Kühl 2000; Gieseke et al. 2003). In fine-grained sediments, mass transfer is governed by diffusion, and local activities can be calculated using diffusion-conversion models (Boudreau 1997). However, in methane-rich sediments (methane hydrates, seeps, and mud volcanoes) the situation can be more complex: porewater flow can be driven by extrusion, degassing, and ventilation by abundant infauna often associated with near-surface methane hydrates. Thus, for the interpretation of microsensor data, insight into the actual mass transfer phenomena is needed.

At Håkon Mosby Mud Volcano (HMMV) we have performed a series of field and laboratory measurements in the four different habitats - center, Beggiatoa mats, Pogonophora fields, as well as in patchy gray mats of unknown sulfide oxidizers - to determine process rates and responsible microorganisms, the distribution of these, and their link to mass transfer phenomena. The essence of the work presented is contained in the in situ and laboratory microsensor measurements. Detailed analysis of the benthic microbial communities will be presented elsewhere (Niemann 2005).

\section{Materials and methods}

Study site and sediment sampling-The measurements were performed during a cruise with the RV Polarstern in July 2003 (ARK XIX/3b). The HMMV has a diameter of ca $1,500 \mathrm{~m}$ and is situated at $1,250 \mathrm{~m}$ in depth $\left(72^{\circ} \mathrm{N}\right.$, $\left.14^{\circ} 44^{\prime} \mathrm{E}\right)$. The whole HMMV area was mapped in high resolution with acoustical and optical methods deployed by the Remotely Operated Vehicle (ROV) 'Victor 6000' (IFREMER, France). This is described in detail elsewhere (Edy and Bisquay 2004; Jerosch et al. 2004). We investigated sediments from the central area, surrounding areas covered with white Beggiatoa mats, gray microbial mats near gas seeps, and areas dominated by Pogonophora tube worms (Table 1). Identical measurements were also performed at a reference site not influenced by the mud volcano, ca $50 \mathrm{~km}$ northwest of the HMMV.

Sediment cores were collected by a camera-guided multicorer (10-cm diameter, ca $40 \mathrm{~cm}$ sediment) and by pushcores manipulated by the ROV (3.6-cm diameter, ca $20 \mathrm{~cm}$ sediment; of the gray mats, the top $5 \mathrm{~cm}$ were sampled). The cores were placed in a cold room $\left(0^{\circ} \mathrm{C}\right)$ directly after retrieval. For microsensor measurements, the cores were placed in an aquarium cooled to in situ temperature $\left(-0.5^{\circ} \mathrm{C}\right)$ by a thermostat (Julabo). The cores were not fully immersed to prevent mixing of the overlying water with the water in the aquarium. The overlying water in the core was gently mixed by a gas jet (air or argon) blown over the surface. Onboard microsensor measurements were performed between 6 and $56 \mathrm{~h}$ after sampling. Unless indicated differently, data are presented from microsensor measurements between 16 and $56 \mathrm{~h}$ after retrieval.

Pore-water chemistry-Samples for pore-water extraction were taken from Beggiatoa cores that were left to recover from degassing at $0^{\circ} \mathrm{C}$ for $12 \mathrm{~h}$, after which the 
Microbial activities in a cold seep

Table 1. Overview of the in situ profile measurements.

\begin{tabular}{lccll}
\hline \hline Date & ${ }^{\circ} \mathrm{N}$ & ${ }^{\circ} \mathrm{E}$ & \multicolumn{1}{c}{ Sensors } & \multicolumn{1}{c}{ Area type } \\
\hline 28 Jun 2003 & $72^{\circ} 0.22^{\prime}$ & $14^{\circ} 43.11^{\prime}$ & $\mathrm{pH}, \mathrm{O}_{2}, \mathrm{H}_{2} \mathrm{~S}$ & Some Beggiatoa \\
30 Jul 2003 & $72^{\circ} 0.159^{\prime}$ & $14^{\circ} 43.887^{\prime}$ & $\mathrm{pH}, \mathrm{T}, \mathrm{O}_{2}, \mathrm{H}_{2} \mathrm{~S}$ & Pogonophora \\
05 Jul 2003 & $72^{\circ} 0.387^{\prime}$ & $14^{\circ} 43.603^{\prime}$ & $\mathrm{pH}, \mathrm{T}, \mathrm{O}_{2}$ & Pogonophora \\
06 Jul 2003 & $72^{\circ} 0.115^{\prime}$ & $14^{\circ} 43.496^{\prime}$ & $\mathrm{pH}, \mathrm{T}, \mathrm{O}_{2}, \mathrm{H}_{2} \mathrm{~S}$ & Beggiatoa \\
07 Jul 2003 & $72^{\circ} 0.282^{\prime}$ & $14^{\circ} 43.460^{\prime}$ & $\mathrm{pH}, \mathrm{O}_{2}, \mathrm{H}_{2} \mathrm{~S}$ & Central area \\
09 Jul 2003 & $72^{\circ} 0.334^{\prime}$ & $14^{\circ} 43.691^{\prime}$ & $\mathrm{T}, \mathrm{O}_{2}, \mathrm{H}_{2} \mathrm{~S}$ & Central area, border Pogonophora \\
11 Jul 2003 & $72^{\circ} 0.148^{\prime}$ & $14^{\circ} 43.630^{\prime}$ & $\mathrm{pH}, \mathrm{T}, \mathrm{O}_{2}, \mathrm{H}_{2} \mathrm{~S}$ & Beggiatoa \\
12 Jul 2003 & $72^{\circ} 0.371^{\prime}$ & $14^{\circ} 43.505^{\prime}$ & $\mathrm{pH}, \mathrm{O}_{2}, \mathrm{H}_{2} \mathrm{~S}$ & Gray mats \\
14 Jul 2003 & $71^{\circ} 59.03^{\prime}$ & $14^{\circ} 45.44^{\prime}$ & $\mathrm{pH}, \mathrm{T}, \mathrm{O}_{2}, \mathrm{H}_{2} \mathrm{~S}$ & Reference site \\
\hline
\end{tabular}

white mat had reestablished. First the mat ( $2 \mathrm{~mm}$ of the top sediment) was removed with a spatula, and then the remaining core was sliced into $1-\mathrm{cm}$ pieces. Cores from gray mats, collected near seeps, were sliced as the Beggiatoa cores. Retrieved cores from the central area and the Pogonophora site were sliced in $0.5-\mathrm{cm}$ (top $2 \mathrm{~cm}$ ) and 1$\mathrm{cm}$ intervals. The mat and sediment slices were frozen and stored at $-20^{\circ} \mathrm{C}$ for later nitrate analysis. The samples were thawed and immediately centrifuged at $3,000 \times \mathrm{g}$ at $0^{\circ} \mathrm{C}$, decanted, and the supernatants were kept on ice. Nitrate plus nitrite in $200-\mu \mathrm{L}$ aliquots was reduced to $\mathrm{NO}$ by $\mathrm{VCl}_{3}$ (Braman and Hendrix 1989) and quantified using a $\mathrm{NO}_{x}$ analyzer (42C NO- $\mathrm{NO}_{2}-\mathrm{NO}_{\mathrm{x}}$ Analyzer, Thermo Environmental Instruments). The measurements were calibrated with defined $\mathrm{NaNO}_{3}$ concentrations in distilled water. Bottom water sampled with Niskin bottles at $50 \mathrm{~cm}$ above the seafloor and acidified to a $\mathrm{pH}$ of 1 for storage was analyzed for nitrate with the same technique.

For sulfate analysis, pore water was extracted from sediment slices using a sediment squeezer driven by pressurized nitrogen (Reeburgh 1967). The pore water was collected in small vials, acidified to a $\mathrm{pH}$ of 2 with $\mathrm{HCl}$, and stored at $2^{\circ} \mathrm{C}$ until later analysis by ion chromatography. For this a Metrohm ${ }^{\mathrm{TM}} 761$ Compact ion chromatograph with chemical suppression and conductivity detector was used, with a $250 \times 4-\mathrm{mm}$ ultra-high-capacity column of the type MetrosepTM A Supp 5. Eluent $\left(3.2 \mathrm{mmol} \mathrm{L}^{-1}\right.$ $\mathrm{Na}_{2} \mathrm{CO}_{3}+1 \mathrm{mmol} \mathrm{L}^{-1} \mathrm{NaHCO}_{3}$ ) was used at a flow of $0.7 \mathrm{~mL} \mathrm{~min}^{-1}$.

Microscopy-The Beggiatoa and gray mats were investigated by microscopy to obtain an impression of the diversity of giant sulfide oxidizers based on morphology. Illumination was done using a transmitting light source and with a Schott light source supplied with fiber optics.

Microsensors-Microsensors for $\mathrm{O}_{2}, \mathrm{H}_{2} \mathrm{~S}$, and $\mathrm{pH}$ were made and used as described previously (Revsbech and Ward 1983; Jeroschewski et al. 1996; De Beer et al. 1997b). The tip diameters were ca $20 \mu \mathrm{m}$; the response time $\left(t_{90}\right)$ was less than $3 \mathrm{~s}$. A temperature sensor was used (Pt100, UST Umweltsensortechnik $\mathrm{GmbH}$ ) that had a length of $18 \mathrm{~cm}$, a shaft and tip diameter of $3 \mathrm{~mm}$, a length of sensing element of $1 \mathrm{~cm}$, and a response time of ca $5 \mathrm{~s}$. The sensors were calibrated after mounting on a free-falling deep-sea profiler, as described previously (Gundersen and Jørgensen 1990;
Wenzhöfer and Glud 2002). The sensors were mounted on the bottom of the titanium housing within a distance of, maximally, $11 \mathrm{~cm}$. The titanium housing, containing amplifiers and a computer for data acquisition and motor control, could be moved vertically by a spindle in a winding on the frame, with a smallest step size of $12.5 \mu \mathrm{m}$. The motor on top of the housing was connected directly to the spindle.

The slope of the $\mathrm{pH}$ calibration was taken, as during the calibration (at least $55 \mathrm{mV}$ per $\mathrm{pH}$ unit); however, usually an off-set was observed in the bottom water, which was corrected for with the $\mathrm{pH}$ determined from Niskin bottle samples from $50 \mathrm{~cm}$ above the sediment surface. The $\mathrm{O}_{2}$ sensors were two-point calibrated in situ by using the signals in the bottom water and in the anoxic zones of the sediments. The bottom-water $\mathrm{O}_{2}$ concentration was measured by Winkler titration from the same Niskin bottles. The detection limit was ca $0.5 \mu \mathrm{mol} \mathrm{L}^{-1}$. Total sulfide was calculated from the local $\mathrm{pH}$ and $\mathrm{H}_{2} \mathrm{~S}$ concentrations (Jeroschewski et al. 1996) using a $\mathrm{pK}$ value for sulfide of 6.92, as calculated from the local temperature and salinity (Millero et al. 1988). The $\mathrm{H}_{2} \mathrm{~S}$ sensors had detection limits for $\mathrm{H}_{2} \mathrm{~S}$ of ca $1 \mu \mathrm{mol} \mathrm{L} \mathrm{L}^{-1}$. Thus, the detection limits for total sulfide $\left(\mathrm{H}_{2} \mathrm{~S}+\mathrm{HS}^{-}+\mathrm{S}^{2-}\right)$ were ca $10 \mu \mathrm{mol} \mathrm{L}^{-1}$ at $\mathrm{pH} 8$ (bottom water and top sediment) and close to $2 \mu \mathrm{mol} \mathrm{L}-1$ at $\mathrm{pH} 7$ (in the deeper sediments). Care was taken that the sensor tips were placed in one horizontal plane with an inaccuracy of, maximally, $1 \mathrm{~mm}$, so that the resulting profiles were aligned. The profiler was preprogrammed to measure one or two vertical profiles, with steps of $250 \mu \mathrm{m}$, over a depth of $17 \mathrm{~cm}$. Each step included a waiting time of $4 \mathrm{~s}$ before a reading was made, consisting of an average of four samplings in a time interval of $4 \mathrm{~s}$. The profiling started ca $6 \mathrm{~h}$ after deployment. All deployments, with the exception of the third and last deployments, were inspected by the ROV to confirm the habitat and quality of deployment. The profiler always stood level with the sediment surface, and the profiled areas were flat in the central areas and Beggiatoa mats, whereas the Pogonophora habitat had irregularities of, maximally, $1 \mathrm{~cm}$. On the free-falling lander a benthic chamber was mounted at a distance of $0.5 \mathrm{~m}$ from the profiling unit. The chamber was pushed into the sediments and the bottom was closed after the profiling, and the containing sediments were retrieved to additionally confirm the type of habitat of the deployment area (central area, Beggiatoa mats, or Pogonophora). For profile analysis, the surface was taken as a reference point (depth $=0)$, defined by the steepest slope of the oxygen 
profile (Gundersen and Jørgensen 1990). Negative depths indicate positions above the surface.

Two deployments were done with the profiler that was specially built for positioning by the ROV. The basic technique was the same (precision of vertical positioning, diameter of the housing), but after positioning by the ROV, the profiling program was started by the ROV with a switch on the profiler. This profiler was not equipped with a temperature sensor.

For use in the laboratory, microsensors were mounted on a motor-driven micromanipulator. In addition to the sensors deployed in situ, these included $\mathrm{N}_{2} \mathrm{O}$ microsensors, with a detection limit of $0.5 \mu \mathrm{mol} \mathrm{L}-1$ (Revsbech et al. 1988). The $\mathrm{N}_{2} \mathrm{O}$ sensors were calibrated in dilutions of $\mathrm{N}_{2} \mathrm{O}$-saturated seawater. Motor action and data acquisition were controlled using a computer. The sediment surface was determined, relative to the microsensor tips, with a dissection scope. The $\mathrm{N}_{2} \mathrm{O}$ sensors were used to detect denitrification from the production of $\mathrm{N}_{2} \mathrm{O}$ upon inhibition of nitrous oxide reduction by acetylene (Revsbech et al. 1988). Acetylene was washed with distilled water to remove acetone and then used to saturate seawater. This was distributed into the sediments using a syringe $(5 \mathrm{~mL}$ per $200 \mathrm{~mL}$ of sediment) and was added to the overlaying water $(5 \mathrm{~mL}$ per $100 \mathrm{~mL})$.

Profile analysis - Local diffusive fluxes (J) of oxygen and sulfide were calculated from microprofiles according to Fick's first law of diffusion, which assumes steady state

$$
J=D_{\text {eff }} \frac{\mathrm{dC}}{\mathrm{dx}}
$$

where $D_{\text {eff }}$ is the effective diffusion coefficient in the sediments and $\frac{\mathrm{dC}}{\mathrm{dx}}$ is the local concentration gradient. $\mathrm{D}_{\text {eff }}$ was calculated from the molecular diffusion coefficient $\left(D_{o}\right)$ and the porosity $(\phi)$ (Ullman and Aller 1982) using

$$
\mathrm{D}_{\text {eff }}=\phi^{2} \mathrm{D}_{0}
$$

$\mathrm{D}_{\mathrm{o}}$ was corrected for salinity (3.5\%) and temperature $\left(-0.5^{\circ} \mathrm{C}\right)$ (Li and Gregory 1974), resulting in a value for oxygen of $1.05 \times 10^{-9}\left(\mathrm{~m}^{2} \mathrm{~s}^{-1}\right)$ and a value for sulfide of $0.79 \times 10^{-9}\left(\mathrm{~m}^{2} \mathrm{~s}^{-1}\right)$. The porosity was determined as the weight loss per volume upon drying to stable weight at $60^{\circ} \mathrm{C}$. The porosity in the central area and Beggiatoa mats varied from ca 0.7 in the top $3 \mathrm{~mm}$ to 0.6 in the sediments below $3 \mathrm{~mm}$; thus, $\mathrm{D}_{\text {eff }}=0.49 \mathrm{D}_{0}$ in the top $3 \mathrm{~mm}$ and $\mathrm{D}_{\text {eff }}$ $=0.36 \mathrm{D}_{0}$ below $3 \mathrm{~mm}$.

Fluid flow determination - To calculate the effect of porewater flow on the reactant profiles, a one-dimensional conversion-transport model, similar to that described previously (Pearson 1986; De Beer et al. 1997a), was used. The model included both advection and diffusion as transport mechanisms:

$$
\mathrm{J}=\mathrm{J}_{\text {diffusion }}+\mathrm{J}_{\text {advection }}=\mathrm{D}_{\text {eff }} \frac{\mathrm{dC}}{\mathrm{dx}}+\mathrm{vC}
$$

where $\mathrm{v}$ is the pore-water flow velocity and $\mathrm{C}$ the local concentration. Conversions considered were respiratory consumption by $\mathrm{O}_{2}$, sulfate reduction by AOM, sulfide oxidation, and aerobic methane oxidation. The model divides the sediment into a number of hypothetical layers and calculates in short time steps the evolution of $\mathrm{O}_{2}$, total sulfide, sulfate, and/or methane profiles from the microbial conversions in each layer and the exchange with the adjacent layers. For each layer, a different set of kinetic and diffusional parameters can be chosen; pore-water flow velocities were the same in all layers. Respiratory $\mathrm{O}_{2}$ consumption and aerobic methane oxidation were not assigned to specific layers but were only dependant on substrate distributions. Sulfate reduction by AOM was assumed to occur below $2 \mathrm{~cm}$ below seafloor (bsf), and sulfide oxidation was assumed to occur between the sediment surface and $2 \mathrm{~cm}$ in depth. Most microbial conversions were assumed to be controlled by MichaelisMenten-type saturation kinetics: the saturation constant for oxygen in the aerobic respiration was assumed to be $10 \mu \mathrm{mol} \mathrm{L}^{-1}$, for sulfate in AOM it was assumed to be $1 \mathrm{mmol} \mathrm{L}{ }^{-1}$, and for sulfide in sulfide oxidation it was assumed to be $10 \mu \mathrm{mol} \mathrm{L}^{-1}$; the maximum conversion rates were $1 \times 10^{-5} \mathrm{~mol} \mathrm{~m}^{-3} \mathrm{~s}^{-1}, 6 \times 10^{-5} \mathrm{~mol} \mathrm{~m}^{-3} \mathrm{~s}^{-1}$, and 6 $\times 10^{-5} \mathrm{~mol} \mathrm{~m}^{-3} \mathrm{~s}^{-1}$, respectively, measured on fresh sediment soon after retrieval (Niemann 2005). Aerobic methane oxidation was assumed to be of the first order for methane. The interfacial concentrations were assumed to be $0.25 \mu \mathrm{mol} \mathrm{L}^{-1}$ for oxygen, $28 \mathrm{mmol} \mathrm{L}{ }^{-1}$ for sulfate, and $0 \mathrm{mmol} \mathrm{L}-1$ for sulfide and methane. If the upflow velocity was greater than zero, the concentrations of oxygen, sulfide, and sulfate were assumed to be equal to zero at $15 \mathrm{~cm}$ in depth. The methane concentration at $15 \mathrm{~cm}$ in depth was assumed to equal 40, 80, or $170 \mathrm{mmol} \mathrm{L}^{-1}$. As an initial condition for the calculation, the sediment between these two boundaries was presumed to be devoid of all reactants. The iterations were continued until a steady state was reached.

A second approach for detecting fluid convection within the pore space was the evaluation of temperature profiles. Nonlinear vertical profiles indicate fluid movement. Temperature gradients were measured by a 3-m-long heat flow probe with 11 temperature sensors (Kaul et al. 2005). From the profiles that showed nonlinearities, eight could be allocated to certain habitats (Table 2). The general onedimensional differential equation for heat transport yields an analytical relation between fluid movement and temperature profiles (Bredehoeft and Papadopulos 1965), thus:

$$
\begin{aligned}
& \frac{\left(\mathrm{T}_{\mathrm{x}}-\mathrm{T}_{0}\right)}{\left(\mathrm{T}_{\mathrm{L}}-\mathrm{T}_{0}\right)}=\frac{e^{\frac{\beta \cdot \mathrm{x}}{\mathrm{L}}}-1}{e^{\beta}-1} \text { or }: \\
& \mathrm{T}_{\mathrm{x}}=\frac{e^{\frac{\beta \cdot \mathrm{x}}{\mathrm{L}}}-1}{e^{\beta}-1}\left(\mathrm{~T}_{\mathrm{L}}-\mathrm{T}_{0}\right)+\mathrm{T}_{0}
\end{aligned}
$$

where $\beta=v c_{0} \rho_{0} \mathrm{~L} / \kappa, \mathrm{L}$ is the length of the temperature profile, $\mathrm{T}$ is the temperature in the profile at its top $\left(\mathrm{T}_{0}\right)$, its bottom $\left(\mathrm{T}_{\mathrm{L}}\right)$, or at defined depths $\mathrm{x}$ in between top and bottom $\left(\mathrm{T}_{\mathrm{x}}\right), \kappa$ is the thermal conductivity, $c_{0}$ the specific heat of the fluid, and $\rho_{0}$ density of the fluid. The solution 
Table 2. Summary of the in situ temperature measurements with the 3-m probe.

\begin{tabular}{ccccc}
\hline \hline${ }^{\circ} \mathrm{N}$ & ${ }^{\circ} \mathrm{E}$ & Area type & $\beta$ & $\begin{array}{c}\text { Upflow velocity } \\
\left(\mathrm{m} \mathrm{yr}^{-1}\right)\end{array}$ \\
\hline $72^{\circ} 0.816$ & $14^{\circ} 42.384$ & Pogonophora & 0.2 & 0.4 \\
$72^{\circ} 0.468$ & $14^{\circ} 43.926$ & Pogonophora & 0.2 & 0.4 \\
$72^{\circ} 0.162$ & $14^{\circ} 43.926$ & Beggiatoa & $0.4-0.6$ & 1.0 \\
$72^{\circ} 0.252$ & $14^{\circ} 43.194$ & Beggiatoa & 0.3 & 0.6 \\
$72^{\circ} 0.258$ & $14^{\circ} 43.722$ & Center & 0.6 & 1.3 \\
$72^{\circ} 0.198$ & $14^{\circ} 43.224$ & Center & 1 & 2.2 \\
$72^{\circ} 0.168$ & $14^{\circ} 43.674$ & Center & $2.5-3.5$ & 5.3 \\
$72^{\circ} 0.252$ & $14^{\circ} 43.772$ & Center & $0.4-0.8$ & 1.3 \\
\hline
\end{tabular}

for a series of $\beta$ values is a set of temperature profiles, which are compared with the measured profiles. Since $\kappa, c_{0}$, $\rho_{0}$, and $\mathrm{L}$ are known, $v$ can directly be calculated from the best-fitting $\beta$ as $6.3072 \beta \mathrm{L}^{-1}\left(\mathrm{~m} \mathrm{yr}^{-1}\right)$. A discrimination of $\beta$ of better than 0.1 is not reasonable, resulting in an uncertainty of $0.2\left(\mathrm{~m} \mathrm{yr}^{-1}\right)$.

Fluid flow in gaseous seeps was measured with an acoustic three-dimensional flow meter (MAVS3TM, Nobska) positioned by the ROV.

\section{Results}

A total of eight microsensor profiler deployments were made (Table 1). Three deployments with the lander-based free-falling profiler were on Beggiatoa-dominated sediments (of which one was at the edge of the mat area), and three were on Pogonophora sites (of which one was at the edge of a Pogonophora field). One deployment was done in the central area, with a profiler specially built for positioning by the ROV. The same profiler was also positioned by the ROV on a patch of gray mat. A last deployment of the free-falling profiler was on a reference site ca $50 \mathrm{~km}$ from the HMMV.

In addition, retrieved sediment cores from all sites were investigated onboard. During retrieval, the hydrostatic pressure was released and the cores were transported through a water column that was slightly warmer than at depth. This resulted in strong degassing causing a mixing of sediments with overlying water and an intrusion of bottom water. The cores had to be left for several hours before the sediment settled and the water became sufficiently transparent for microsensor positioning. The disturbed Beggiatoa mats reestablished on top of the sediment 6-12 $\mathrm{h}$ after retrieval. The diffusive influx of oxygen from the bottom water into the sediments and the upward sulfide flux from deeper sediments into the sulfide-free surface sediments were calculated from the steepest part of the microprofiles both from the in situ and ex situ profiles (Table 3). The bottom-water analyses showed that the $\mathrm{pH}$ was ca 7.9 above the Pogonophora and Beggiatoa sediments and 8.1 above the central area; oxygen varied between 260 and $290 \mu \mathrm{mol} \mathrm{L}-1$ and nitrate concentrations varied from 12 $18 \mu \mathrm{mol} \mathrm{L}^{-1}$.

Central site-Visual observations with ROV Victor showed a slightly undulating surface and an absence of
Table 3. Summary of the diffusive fluxes calculated from the microprofiles that were measured in situ with an autonomous profiler and in retrieved cores on the ship. The sulfide fluxes indicate upward (first number) and downward (in parentheses) fluxes and the total production (sum of upward and downward in bold type). The total oxygen flux in the center in the central site is also given (i.e., the diffusional influx corrected for advection efflux; *). The in situ fluxes in gray mats and the total sulfide in the Pogonophora site could not be calculated (nc).

\begin{tabular}{|c|c|c|c|c|}
\hline & \multicolumn{2}{|c|}{$\begin{array}{l}\text { Diffusive fluxes, in situ } \\
\left(\mathrm{mol} \mathrm{m}^{-2} \mathrm{~s}^{-1}\left(\times 10^{7}\right)\right)\end{array}$} & \multicolumn{2}{|c|}{$\begin{array}{l}\text { Diffusive fluxes, retrieved } \\
\text { cores }\left(\mathrm{mol} \mathrm{m}^{-2} \mathrm{~s}^{-1}\right. \\
\left.\left[\times 10^{7}\right]\right)\end{array}$} \\
\hline & $\mathrm{O}_{2}$ & Sulfide & $\mathrm{O}_{2}$ & Sulfide \\
\hline Beggiatoa & $1.29 \pm 0.45$ & $\begin{array}{c}2.16 \pm 0.3 \\
(0.44 \pm 0.4) \\
\mathbf{2 . 6 0}\end{array}$ & $0.86 \pm 0.63$ & $\begin{array}{c}1.46 \pm 0.5 \\
(0.15 \pm 0.05) \\
\mathbf{1 . 6 1}\end{array}$ \\
\hline Pogonophora & $0.20 \pm 0.06$ & $\mathrm{nc}$ & $0.22 \pm 0.07$ & $\mathrm{nc}$ \\
\hline Central site & $1.20 \pm 0.4^{*}$ & 0 & $0.16 \pm 0.05$ & $0.04 \pm 0.02$ \\
\hline Gray mats & $\mathrm{nc}$ & $\mathrm{nc}$ & 1.5 & 0.76 \\
\hline Reference & $0.10 \pm 0.01$ & 0 & $0.33 \pm 0.023$ & 0 \\
\hline
\end{tabular}

microbial mats in the center of the mud volcano, characterized by grayish muds. Seepage of free gas was only observed at three sites to the north of the central area, but not in the center of the HMMV.

In situ: Oxygen penetrated to 1-2 $\mathrm{mm}$ bsf and the diffusive uptake was very high (Table 3 ). The sulfide concentrations were below $10 \mu \mathrm{mol} \mathrm{L}^{-1}$ (Fig. 1). The low sulfide levels indicate that AOM is low or absent at the central site. The single in situ $\mathrm{pH}$ profile obtained showed the $\mathrm{pH}$ to decrease from 8.1 in the seawater to 6.8 at $1 \mathrm{~cm}$ bsf. At such a low $\mathrm{pH}$ the detection limit for total sulfide is ca $2 \mu \mathrm{mol} \mathrm{L}^{-1}$. In the central area, four temperature profiles were recorded to $3 \mathrm{~m}$ bsf (Fig. 2A; Table 2), with a curvature indicative of high pore-water flow.

Retrieved cores: The retrieved sediments from the central site showed steep oxygen profiles, with oxygen penetrating only $1-3 \mathrm{~mm}$. Some sulfide was detected; however, the profiles were variable and unstable (Fig. 3). The $\mathrm{pH}$ profiles were highly variable, sometimes almost flat, in other cores, irregularly decreasing with depth from 7.8 to 7.4. It is likely that the cores were strongly disturbed by the retrieval procedure. The oxygen fluxes were only $15 \%$ of the estimate derived from an in situ profile (Table 3). The oxygen uptake rates were much higher than the upward fluxes of sulfide. Nitrate decreased from $2-3 \mu \mathrm{mol} \mathrm{L}^{-1}$ in the top centimeter to less than $1 \mu \mathrm{mol} \mathrm{L}-1$ deeper in the sediment. A sulfate profile from a retrieved core showed a rapid decrease in the top zone to nondetectable levels (Fig. 4).

Beggiatoa site-Adjacent to the center of this site is an area characterized by a relatively flat surface, with highly reduced dark-gray sediments covered by white bacterial mats. There were no fluid or gas seeps found in the Beggiatoa area. 


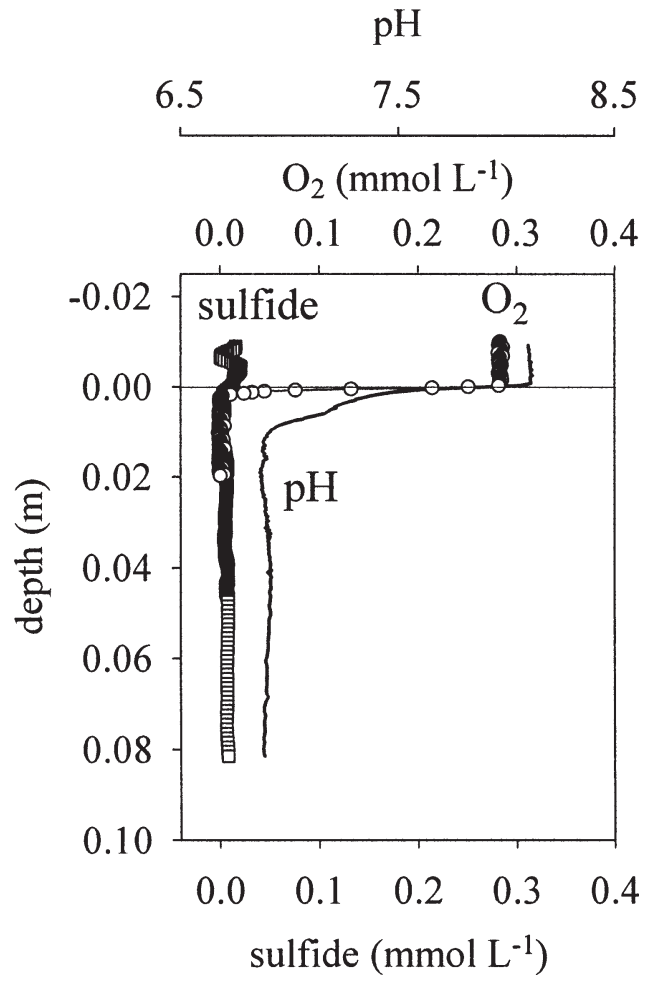

Fig. 1. Microprofiles in sediment from the central area, measured in situ. The microprofiler was positioned by the ROV. The slight irregularities of the sulfide profile above the sediment may be an effect of the strong ROV lights.

In situ: At the Beggiatoa site, oxygen penetrated ca $1 \mathrm{~mm}$, and a distinct sulfide peak was observed at $2-3 \mathrm{~cm}$ bsf (Fig. 5). Here, the sulfide concentration reached a maximum of ca $4 \mathrm{mmol} \mathrm{L}^{-1}$. Below the subsurface peak a quick decrease was observed. The zone of sulfide formation was less than $0.5 \mathrm{~cm}$ thick. Sulfide and oxygen did not overlap, as sulfide was depleted in the top 5-
$10 \mathrm{~mm}$, leaving a gap of ca $6 \mathrm{~mm}$ between the oxic and sulfidic zone (Fig. 5B). Similar oxygen profiles were found at the border of the Beggiatoa field, but the sulfide profiles were less steep, with a peak at or below $12 \mathrm{~cm}$ in depth (data not shown). The sulfide diffusion from the peak upward to the oxic zone was approximately twice as high as the diffusive oxygen influx (Table 3). The $\mathrm{pH}$ in the overlying seawater was ca 7.9. In the sediment the $\mathrm{pH}$ decreased gradually with depth to a value close to 7.2 at $12 \mathrm{~cm}$ below the sediment surface. No remarkable deviation in $\mathrm{pH}$ was observed near the sulfide peak or at the zone where sulfide disappeared. The temperature was constant in the water column $\left(-0.9^{\circ} \mathrm{C}\right)$ but increased almost linearly with sediment depth $\left(-0.65^{\circ} \mathrm{C}\right.$ at a depth of $15 \mathrm{~cm})$. In Beggiatoa mats, two temperature profiles were recorded with the 3-m probe, showing slightly curved temperature profiles indicative of a small upward flow velocity (Fig. 2B; Table 2).

Retrieved cores: Despite the disturbances induced by the retrieval, the microprofiles measured in cores from the Beggiatoa sites were surprisingly similar to the profiles measured in situ (Figs. 5, 6). Oxygen penetrated ca $2 \mathrm{~mm}$. Nitrate profiles, obtained from extracted pore water, showed that the upper sediment layer from the Beggiatoa site contained much higher nitrate concentrations than did the seawater $\left(12-18 \mu \mathrm{mol} \mathrm{L}^{-1}\right)$. The 2-mm-thick layer of Beggiatoa contained ca $230 \mu \mathrm{mol} \mathrm{L}^{-1}$ nitrate, and the first 1-cm-thick layer sediment layer contained ca $300 \mu \mathrm{mol} \mathrm{L}^{-1}$ (Fig. 6C). The extraction procedure was designed to disrupt the Beggiatoa cells; thus, the nitrate peaks reflect an intracellular nitrate pool corresponding to $300 \mu \mathrm{mol} \mathrm{L}^{-1} \mathrm{NO}_{3}^{-}$dissolved in the pore water. Below this zone, nitrate concentrations were less than $10 \mu \mathrm{mol} \mathrm{L}^{-1}$. Also at this site, the sulfate concentration decreased rapidly to depletion at $5 \mathrm{~cm}$ bsf (Fig. 4).

The $\mathrm{pH}$ and sulfide profiles were slightly irregular, probably as a result of the remaining gas bubbles. Under
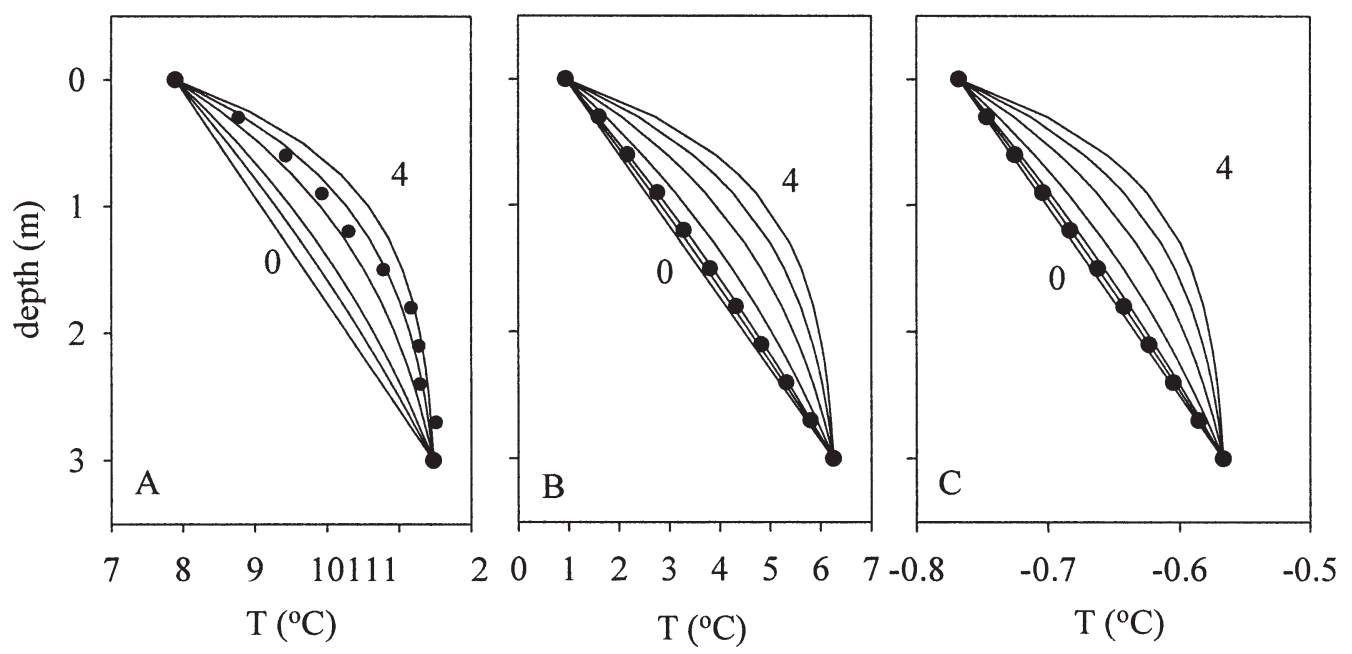

Fig. 2. Temperature profiles recorded in (A) a center site, (B) a Beggiatoa mat, and (C) a Pogonophora site, with the 3-m probe (symbols). The solid lines represent modeled temperature profiles assuming different upflow velocities (Eq. 3 ). For the center site, $\beta$ was 0 , $0.5,1,2,3$, and 4 ; for the two other sites, $\beta$ values of $0,0.2,0.4,1,2,3$, and 4 were used; the two extreme $\beta$ values are indicated by numbers in the plot. 


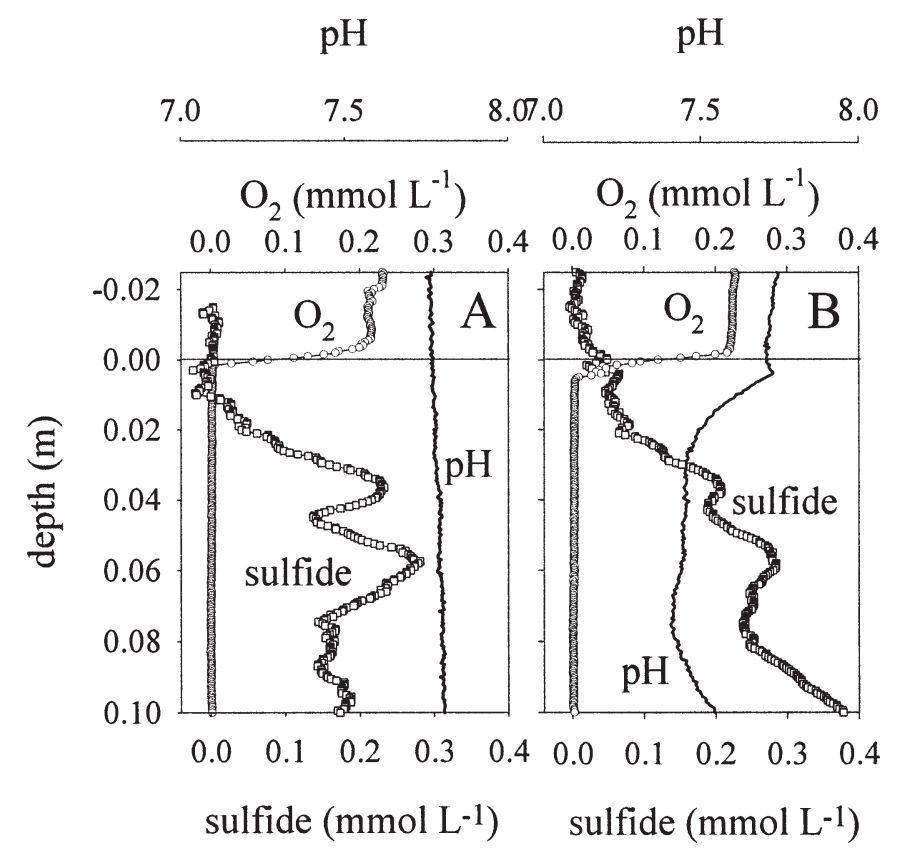

Fig. 3. Microprofiles in sediment from the central area, measured in retrieved cores. The $\mathrm{pH}$ and sulfide profiles were irregular. (A) Data measured within $12 \mathrm{~h}$ after retrieval and (B) data measured after $24 \mathrm{~h}$.

the Beggiatoa mats a sulfide peak was found at $3-5 \mathrm{~cm}$ in depth. The peak was usually $1-2 \mathrm{~cm}$ wide, and sulfide concentrations of ca $4-5 \mathrm{mmol} \mathrm{L}^{-1}$ were measured. In freshly retrieved cores oxygen and sulfide overlapped, but after $36 \mathrm{~h}$ a separation of several millimeters was established between the oxic and the sulfidic zone (Fig. 7).

The diffusive oxygen uptake by the Beggiatoa mats, measured in retrieved cores, was $30 \%$ lower than it was in situ (Table 3). Also, the upward diffusive flux estimates of sulfide were less than in situ estimates.

Effects of oxygen and nitrate on sulfide microprofiles: To study the effect of supply of electron acceptor on SO in Beggiatoa mats, the oxygen concentration was reduced from $0.36 \mathrm{mmol} \mathrm{L}^{-1}$ to $0.05-0.08 \mathrm{mmol} \mathrm{L}^{-1}$ by purging with argon for a period of $36 \mathrm{~h}$. This treatment had no effect on the sulfide profiles (data not shown). Beggiatoa are known to use nitrate to oxidize sulfide. Therefore, we subsequently added nitrate to a concentration of $200 \mu \mathrm{mol} \mathrm{L}^{-1}$ for a period of $6 \mathrm{~h}$, after which the concentration was increased to $400 \mu \mathrm{mol} \mathrm{L}^{-1}$ for a period of $4 \mathrm{~h}$. Also, nitrate additions did not have an effect on the sulfide distribution (data not shown).

Beggiatoa mats were exposed to acetylene, which blocks the last step of denitrification, resulting in formation of $\mathrm{N}_{2} \mathrm{O}$ instead of $\mathrm{N}_{2}$. During the treatment, $\mathrm{N}_{2} \mathrm{O}$ microprofiles were measured continuously. No development of $\mathrm{N}_{2} \mathrm{O}$ was observed, indicating the absence of nitrous oxide reduction to $\mathrm{N}_{2}$.

Gray mats-The gray mats were found near gas ebullition sites and open seeps at the transition zone between the central area and the Beggiatoa mats. In several of the areas with gray mats the seafloor was irregular,

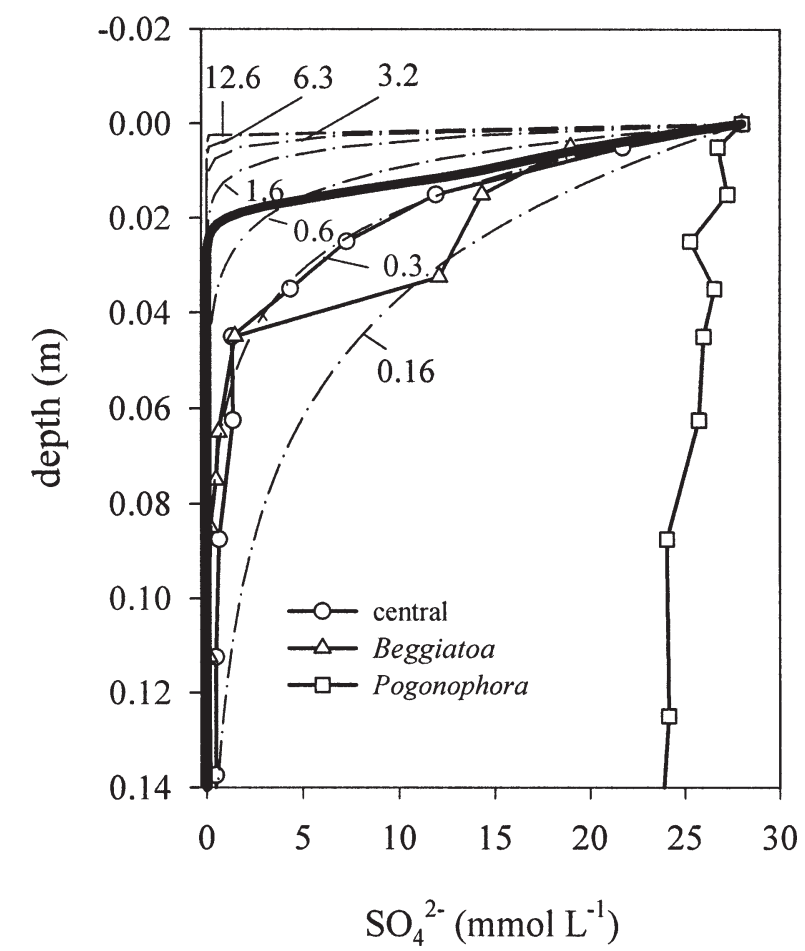

Fig. 4. Sulfate profiles measured on retrieved cores. Although the overlaying water has mixed with the pore water during retrieval, it is clear that a rapid decrease to depletion occurs in the sediments from the central area and the Beggiatoa site, but not in the sediments from the Pogonophora site. The dashed lines represent modeled sulfate profiles under different upflow velocities calculated with Eq. 4. The numbers indicate the upflow velocities in $\mathrm{m} \mathrm{yr}^{-1}$. Upflow of sulfate-free pore water limits sulfate penetration to the very top of the sediments. The thick solid line without symbols is the sulfate profile calculated with the diffusion-advection-conversion model at a flow velocity of $0.4 \mathrm{~m} \mathrm{yr}^{-1}$.

indicating dynamic turnover of the sediments, possibly by gas ebullition. The fluid flow in two such seeps, measured with the acoustic flow meter, was $\mathrm{ca} 1 \mathrm{~cm} \mathrm{~s}^{-1}$. The top layer of the sediment resembled Beggiatoa mats, although the mats were less smooth and were mostly gray instead of white.

In situ: In situ data were obtained by a microprofiler, which was positioned by the ROV; this method represents the only way to study these rare and localized habitats. The $\mathrm{pH}$ and oxygen profiles are single observations and are rather noisy (probably because of connection problems), but combined with the sulfide data, they showed the relevant zonations (Fig. 8). Unlike the case with the Beggiatoa mats, sulfide reached the surface and overlapped with the oxic zone, allowing aerobic SO. The $\mathrm{pH}$ showed a dip near the surface. The data quality did not allow for calculation of fluxes.

Retrieved cores: A more-detailed set of microprofiles were obtained from retrieved cores, which showed essentially the same phenomena as in situ samples (Fig. 9). Also, sulfide was here measured close to the surface and 


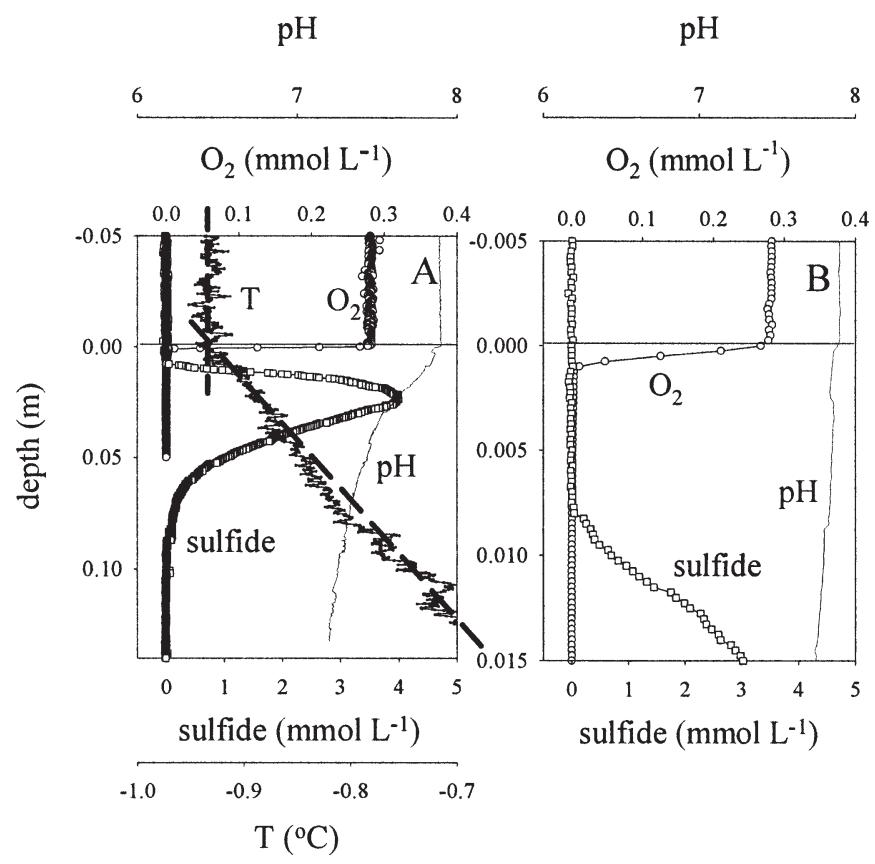

Fig. 5. (A) Microprofiles in sediment from the Beggiatoa mats, measured in situ. The microprofiler was deployed with a free-falling lander. (B) The same profiles rescaled near the sediment surface, showing the separation between the sulfidic and oxic zones. The dashed lines through the linear parts of the temperature profiles intersect near the sediment surface.

overlapped with the oxygen profile. The sulfide concentrations were much higher than those obtained when measured in situ, a difference that is attributed to the heterogeneity of the habitat and the inherent difficulty of positioning the in situ profiler on the representative spot. Oxygen penetrated ca $2 \mathrm{~mm}$, as was the case with the
Beggiatoa mats. The $\mathrm{pH}$ and the sulfide profiles were different from those measured in the Beggiatoa mats. The $\mathrm{pH}$ profiles were variable and rather irregular, but they showed a distinct dip at ca $2-4 \mathrm{~mm}$ in depth. The oxygen fluxes in this mat were twice as high as the sulfide fluxes, in contrast to sediments covered by Beggiatoa mats, in which the opposite was observed (Table 3).

After the microsensor measurements, three subsamples of gray mat material were taken and were found to contain $0.14,1.2$, and $3 \mathrm{mmol} \mathrm{L}^{-1}$ nitrate, whereas the water column in the cores contained only $8.5 \mu \mathrm{mol} \mathrm{L}^{-1}$ nitrate. Thus, community members of the gray mats also accumulate nitrate. Apparently the nitrate-accumulating organisms are distributed heterogeneously in this type of microbial mat.

A microscopy study of the white Beggiatoa mats and the gray mats showed large differences in communities of big bacteria. The mats from the Beggiatoa site showed a uniform morphotype, with filaments of ca $10 \mu \mathrm{m}$ in diameter. All observed filaments contained sulfur globules. In contrast, the gray mats were highly diverse, with a large number of filamentous bacteria with a thickness varying from $1-2 \mu \mathrm{m}$ to $12 \mu \mathrm{m}$. A fraction of the filaments contained sulfur inclusions, and in addition, filaments without visible sulfur globules were observed. Occasionally, large spherical cells with sulfur inclusions were observed, having a diameter that varied from 50 to $125 \mu \mathrm{m}$. The microscopy was documented by photography; however, as a result of ship vibrations, these results were unsuitable for publication.

Pogonophora site-The sediments in the Pogonophora area had a more irregular microtopography than observed at the central and Beggiatoa sites. The sediments were densely colonized by pogonophoran tube worms. Their

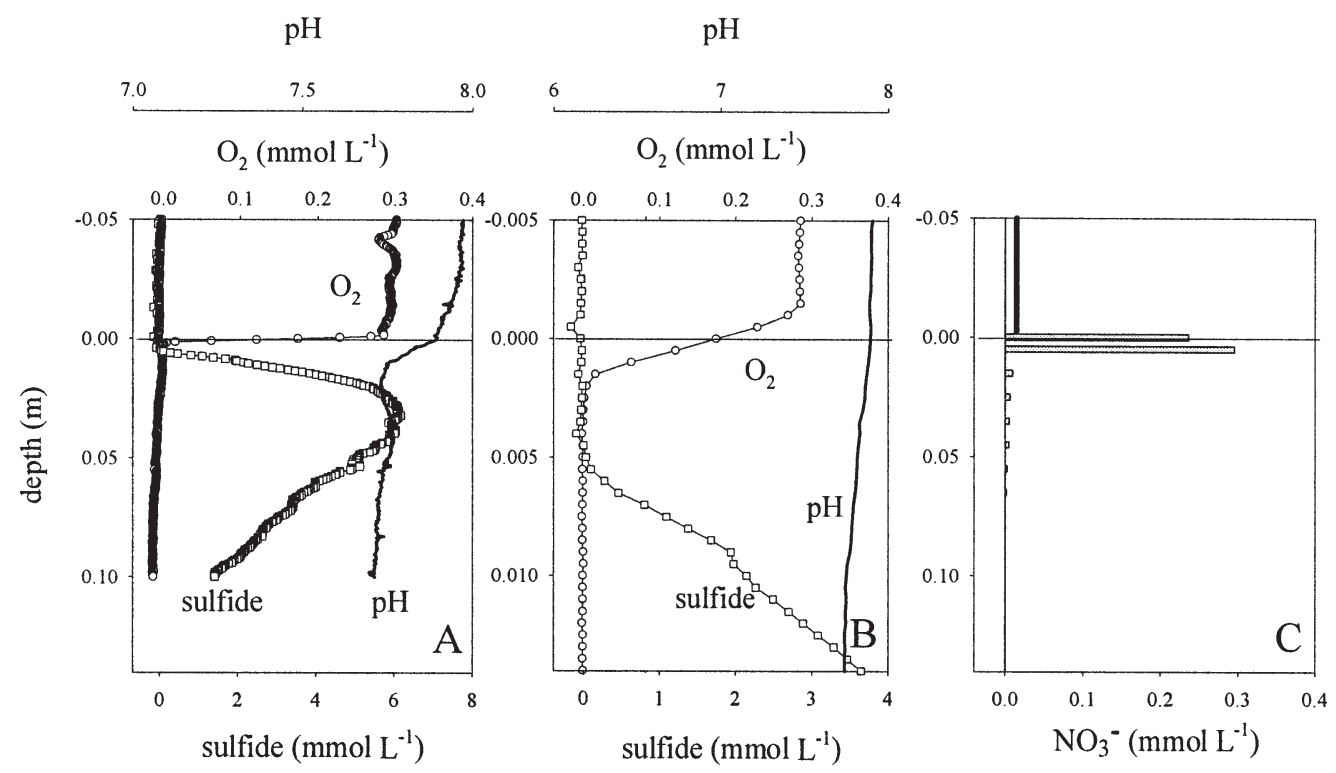

Fig. 6. (A) Microprofiles in sediment from the Beggiatoa mats, measured in retrieved cores. (B) The same profiles rescaled near the sediment surface, showing the separation between the sulfidic and oxic zones. (C) A nitrate profile obtained by pore-water extraction; the peak reflects intracellular nitrate. The solid line is the seawater concentration measured from Niskin bottles. 


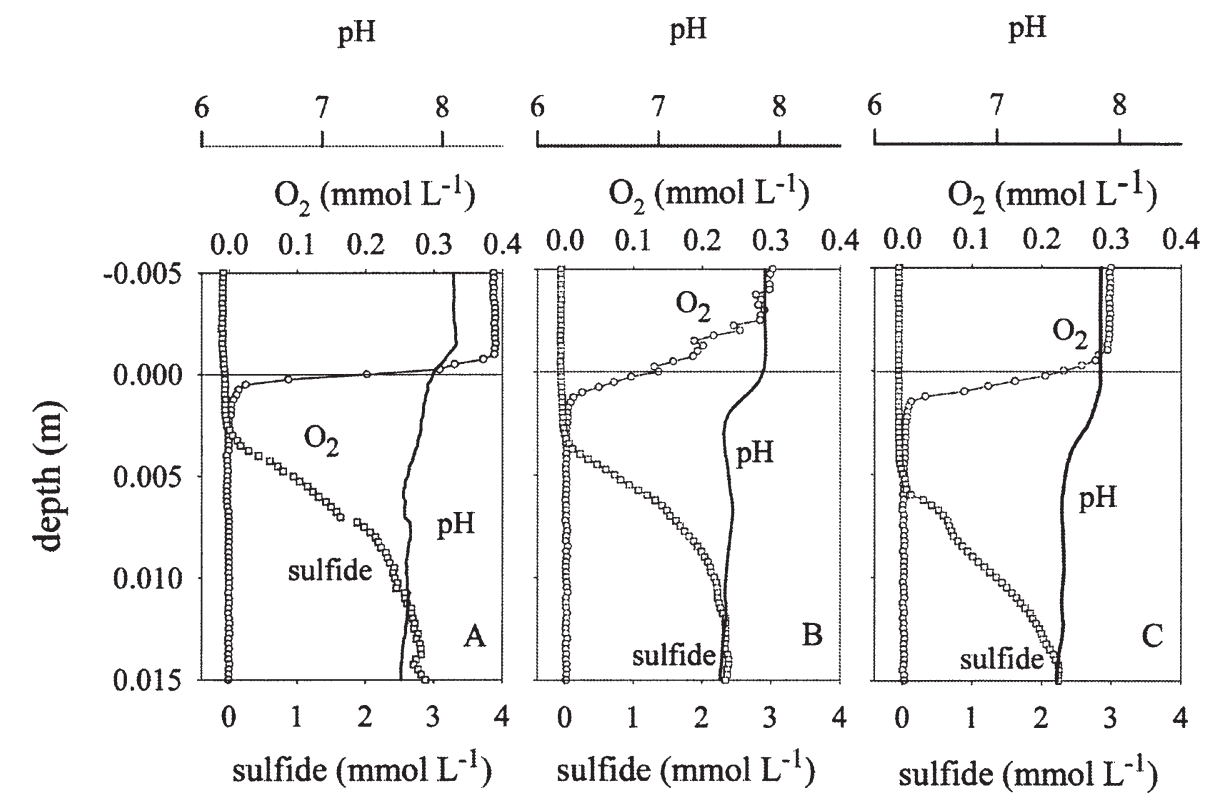

Fig. 7. Time series of microprofiles in sediment from the Beggiatoa mats, measured in retrieved cores. (A) The situation $4 \mathrm{~h}$ after retrieval, (B) $12 \mathrm{~h}$ after retrieval, and (C) $36 \mathrm{~h}$ after retrieval. After the retrieval the separation between the oxic and sulfidic phases recovers.

chitin tubes extended several centimeters into the bottom water and reached down to $70 \mathrm{~cm}$ below the sediment surface. The sediments and tubes were covered with a thin layer of detrital material. The site hosted an abundant fauna.

In situ: The profiles at the Pogonophora site were rather irregular, particularly those recorded by the deeper-reaching $\mathrm{pH}$ and sulfide sensors (Fig. 10A,B). The sensors always broke during these deployments because of the hard chitin tubes of the worms. The irregularity of the $\mathrm{pH}$ values made alignment with the $\mathrm{H}_{2} \mathrm{~S}$ profiles inaccurate; thus, the total sulfide profiles could not be calculated from the local $\mathrm{pH}$ and $\mathrm{H}_{2} \mathrm{~S}$ values. Oxygen penetrated deeper into these sediments than into Beggiatoa-covered sediments. In one deployment, the oxic zone was $3 \mathrm{~cm}$; in a second deployment it was over $10 \mathrm{~cm}$ thick. $\mathrm{H}_{2} \mathrm{~S}$ and $\mathrm{O}_{2}$ profiles overlapped, allowing aerobic SO. However, maximal $\mathrm{H}_{2} \mathrm{~S}$ concentrations were $<150 \mu \mathrm{mol} \mathrm{L}^{-1}$. The temperature microprofiles showed that instead of a linear temperature increase from sediment surface to depth, as was observed under the Beggiatoa mats, the top $5 \mathrm{~cm}$ of the sediment had the temperature of seawater, indicating advective exchange of seawater and pore water in this horizon. Below this zone, the temperature increased with sediment depth. The diffusive oxygen uptake in this site was only $15 \%$ of that in the Beggiatoa site. However, this is very likely an underestimation of the total oxygen uptake, as advection due to ventilation by worms will dominate the sedimentwater exchange. No diffusive sulfide fluxes were calculated, as the total sulfide concentration profiles were not obtained.

Deep-probing temperature profiles to $3 \mathrm{~m}$ in depth were recorded twice, showing a very small curvature indicative of a very small net upward pore-water velocity (Fig. 2C; Table 2).

Retrieved cores: The profiles in the sediments from the Pogonophora sites were changed significantly by the retrieval procedure (Fig. 10A,C). As a result of repeated breaking of the microsensors, profiling data are restricted to the top $6 \mathrm{~cm}$. Oxygen penetration was ca $1 \mathrm{~cm}$, instead of $3-10 \mathrm{~cm}$, as observed in situ. No sulfide was detected in the retrieved cores. This indicates that the sulfide measured in the seafloor was actively transported upward by the worms.

The sulfate profiles did not show a significant decrease in the top $15 \mathrm{~cm}$ of the sediment, as was observed in the central area and Beggiatoa site (Fig. 4). A gradual decrease in sulfate concentration to depletion at a depth of $70 \mathrm{~cm}$ was measured (data not shown).

The diffusive oxygen exchange by the Pogonophorainhabited sediments was the same in retrieved cores as it was in situ, although the oxygen concentration in the bottom water was higher during the laboratory measurements. The pore water from the top centimeter contained $18 \mu \mathrm{mol} \mathrm{L}-1$ nitrate, close to the bottom-water concentration, which decreased to less than $1 \mu \mathrm{mol} \mathrm{L} \mathrm{L}^{-1}$ within $3 \mathrm{~cm}$.

Reference site-The site was not inspected by the ROV, so no visual information on the seafloor structure is available.

In situ: The reference site did not contain methane in the sediments. Here, the diffusive oxygen uptake rate was low (Table 3) and oxygen penetration was ca $5 \mathrm{~cm}$. The $\mathrm{pH}$ decreased gradually from 7.9 to 7.2 , and no sulfide was 

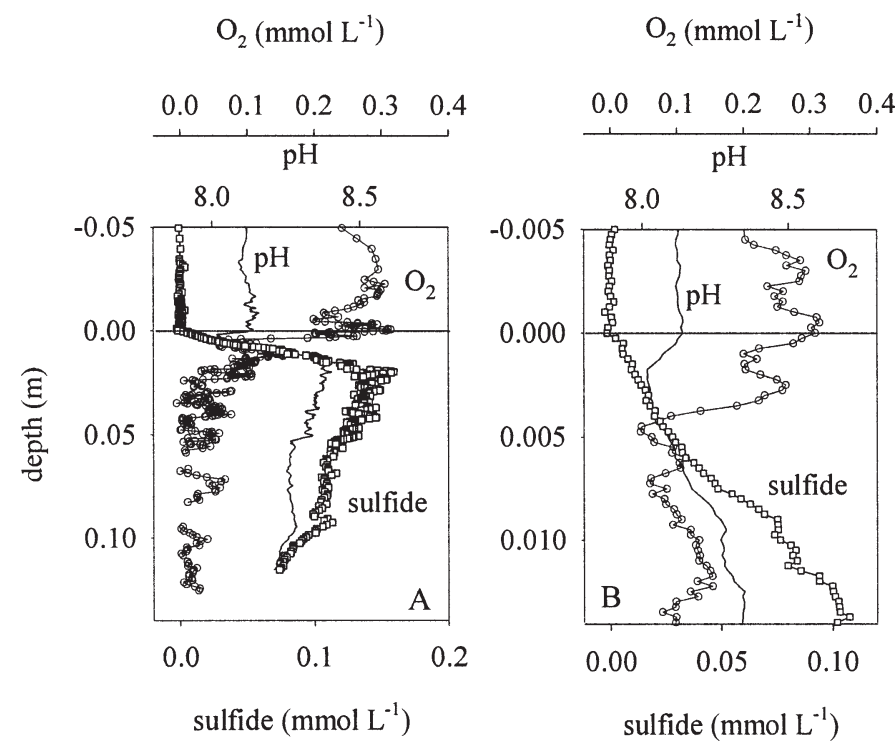

Fig. 8. (A) Microprofiles in sediment from the gray mats, measured in situ. The microprofiler was deployed with the ROV. (B) The same profiles rescaled near the sediment surface, showing the overlap of the sulfidic and oxic zones. The profiler was not equipped with a temperature microsensor.

detected (Fig. 11A). The temperature was constant at $-0.9^{\circ} \mathrm{C}$ in the top $15 \mathrm{~cm}$.

Retrieved cores: In contrast to the HMMV sites, sediment retrieved from the reference site increased in activity, leading to a threefold increase in the oxygen uptake and reduction of the penetration depth (Fig. 11B). The retrieved sediments from the reference site showed a sharp $\mathrm{pH}$ decrease within the top $1 \mathrm{~cm}$ and an oxygen penetration of ca $1 \mathrm{~cm}$, versus $5 \mathrm{~cm}$ in situ. The sulfate concentration in the top $15 \mathrm{~cm}$ was the same as in seawater.

\section{Discussion}

The microsensor measurements reported here represent the first in situ characterization of the microenvironments in methane-rich cold seep sediments with high rates of AOM (Niemann 2005). The results show that the mud volcano is a highly active and diverse environment. The abundant fauna gives evidence that the HMMV ecosystem is supported by high rates of chemolithotrophic biomass production. Methane is supplied from deep sediments by slowly upward-moving methane-rich fluids. The upwardmoving pore water is devoid of suitable electron acceptors. Previous analyses of the subsurface fluids of HMMV showed a conspicuous depletion in bromide and chloride indicative of dilution with freshwater, as caused by subsurface clay dewatering (Lein et al. 1999). Hence, the sulfate and oxygen needed for methane oxidation is supplied from the water column only. Our results based on microsensor profiles and temperature measurements indicate that it is fluid flow and electron (e)-acceptor transport mechanisms that determine the differences between the habitats. Alternatively, it can be assumed that

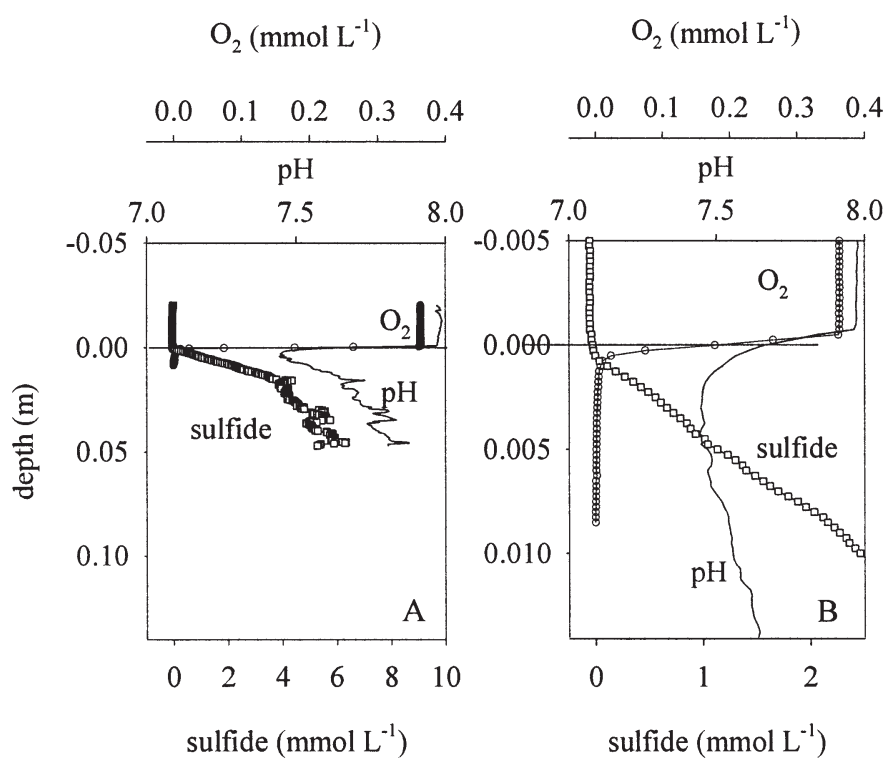

Fig. 9. (A) Microprofiles in sediments retrieved from the gray mats. (B) Rescaled to better show the profiles in the top sediment. Clearly sulfide and oxygen overlap, and the $\mathrm{pH}$ dip indicates aerobic SO.

disturbances by mud flows and sediment deposition may affect the development of biological communities. In the following, the different habitats at HMMV are compared and our results are discussed with regard to factors structuring the communities at HMMV.

The chemolithotrophic processes can roughly be divided into aerobic methane oxidation in the central area and AOM coupled with anaerobic SO under the Beggiatoa mats. In the gray mats, AOM maybe controlled by irregular downflow of sulfate during ebullition, and a significant part of the sulfide is oxidized aerobically. At the Pogonophora site, a part of the methane is anaerobically oxidized in the deeper sediments (Niemann 2005), above which the produced sulfide and the possibly remaining methane are oxidized aerobically by the symbiotic Pogonophora and/or free-living aerobic methane- and sulfideoxidizing bacteria.

Core retrieval had effects on the biogeochemistry that differed depending on the site characteristics. It has been observed that sediments retrieved from the oxic deep-sea floor exhibit increased rates of oxygen consumption in response to increased temperatures and pressure reduction (Glud et al. 1994; Sauter et al. 2001; Wenzhöfer and Glud 2002). This was indeed observed at our reference site. However, the sediments from the central area and the Beggiatoa mats seemed to have a decreased oxygen uptake rate after retrieval. Ex situ profiles from the central area and Beggiatoa area were less steep than those measured in situ. Retrieval cuts off fluid flow and methane is lost from solution as a result of depressurization, probably decreasing the volumetric respiration rates driven by methane oxidation. This underscores the importance of direct measurements for quantification of natural phenomena. Nevertheless, the measurements on retrieved cores from the 

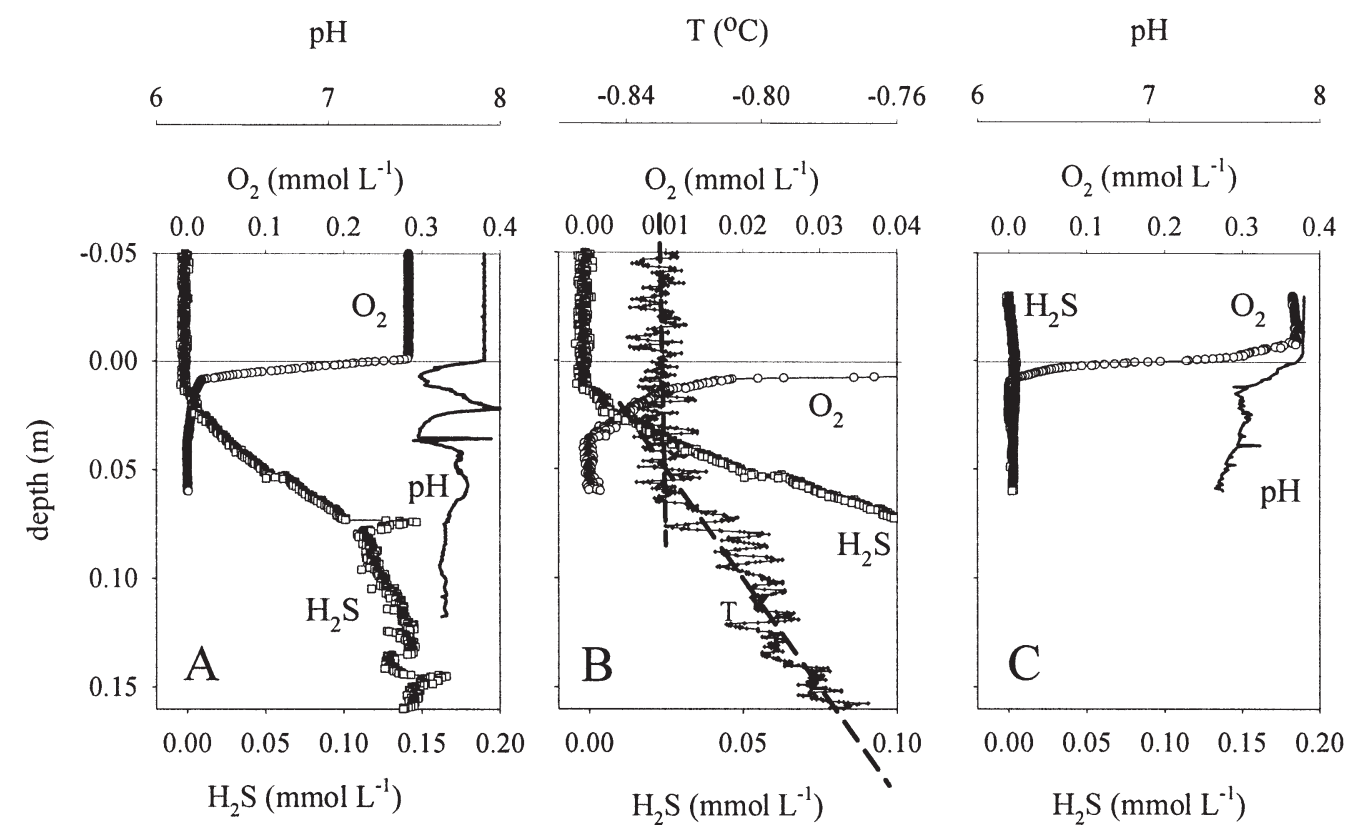

Fig. 10. (A) Microprofiles in sediment from the Pogonophora site, measured in situ. The microprofiler was deployed with a freefalling lander. (B) The rescaled oxygen and sulfide profiles show that here the oxic and sulfidic zones overlap. The dashed lines through the linear parts of the temperature profiles intersect at ca $5 \mathrm{~cm}$ in depth, demonstrating intense ventilation of the top sediments. (C) Microprofiles measured in retrieved cores.

Beggiatoa site allowed precise positioning of the different sensors and confirmed the essential in situ observations: a narrow sulfide peak at a few centimeters in depth, no clear $\mathrm{pH}$ shifts in the AOM zone, and no overlap of sulfide and oxygen profiles. The reduction in oxygen uptake can be explained by a combination of (1) the reduction of the methane concentration in the sediments (i.e., reduction of AOM and aerobic methane oxidation) and (2) changes in mass transfer mechanisms by the retrieval, as will be discussed in the following paragraph.

Mass transfer phenomena-The main mass transfer phenomena at HMMV explain the observed in situ porewater profiles. The volcano resembles a three-phase reactor system in which sediments, water, and gases move upward with different velocities, thus inducing advection. The porewater upflow through the sediments is, as in any threephase system, certainly a heterogeneous phenomenon, and the observed fluid seeps can be considered as focal points for pore-water flow. In addition, at the Pogonophora sites, bioirrigation was a significant transport process. In the HMMV area, heat is transported from the deep sediments to the water column. We used the temperature profiles to assess whether bioventilation was significant. Since heat is not significantly dissipated or produced in the top layers of the sediment, linear temperature profiles can indicate the absence of flow, and deviations from linearity indicate advection. Upward advection leads to convex profiles or, in extreme cases, to a stepwise change in temperature at the sediment-water interface. Downward advection or mixing of seawater with pore water (bioirrigation) will lead to equilibration of the sediment temperature with seawater. This would result in a concave profile or a constant seawater temperature inside sediments. In the sites in which Pogonophora are abundant, we observed an equilibration of the seawater temperature in the top 5-10 cm, caused by ventilating activities of the worms. A large discrepancy between the diffusive and total fluxes can be expected at the Pogonophora sites as a result of these advective transport processes. The significant advectional term prohibits the application of diffusion-conversion modeling, and microprofiles from Pogonophora sites were not used for quantification of local exchange rates.

The linear increase of temperature over the top $15 \mathrm{~cm}$ at the Beggiatoa site might indicate that Fick's law of diffusion (Eq. 1) can be used for the analyses of the microprofiles in Beggiatoa sediments to calculate net fluxes and localization of active zones. However, heat conduction is faster than diffusion of solutes. Thus, very small porewater flows cannot be detected from these temperature profiles, but they can still influence the microprofiles from substrates and products. Small pore-water upflow velocities can only be calculated from much longer temperature profiles (e.g., over the top $3 \mathrm{~m}$ ).

A clear indication for a slow pore-water flow is the decrease of sulfide below the AOM zone under the Beggiatoa mats. It is unlikely that an oxidant for sulfide is present in these highly reduced sediments below $3 \mathrm{~cm}$, and precipitation cannot be sustained for a long time because of depletion of the co-precipitating ion (e.g., iron). Hence, we can assume that this phenomenon must be caused by upward flow of sulfide-free pore water. In a steady state, the diffusive sulfide flux downward $\left(\mathrm{J}_{\mathrm{D}}\right)$ are equal to the advectional flux upward $\left(\mathrm{J}_{\mathrm{adv}}\right)$, thus $\mathrm{J}_{\mathrm{adv}}=\mathrm{J}_{\mathrm{D}}$ and $\mathrm{vC}=\mathrm{D}_{\text {eff }} \mathrm{dC} / \mathrm{dx}$, which can be integrated over depth. With the boundary condition that the interface concentra- 


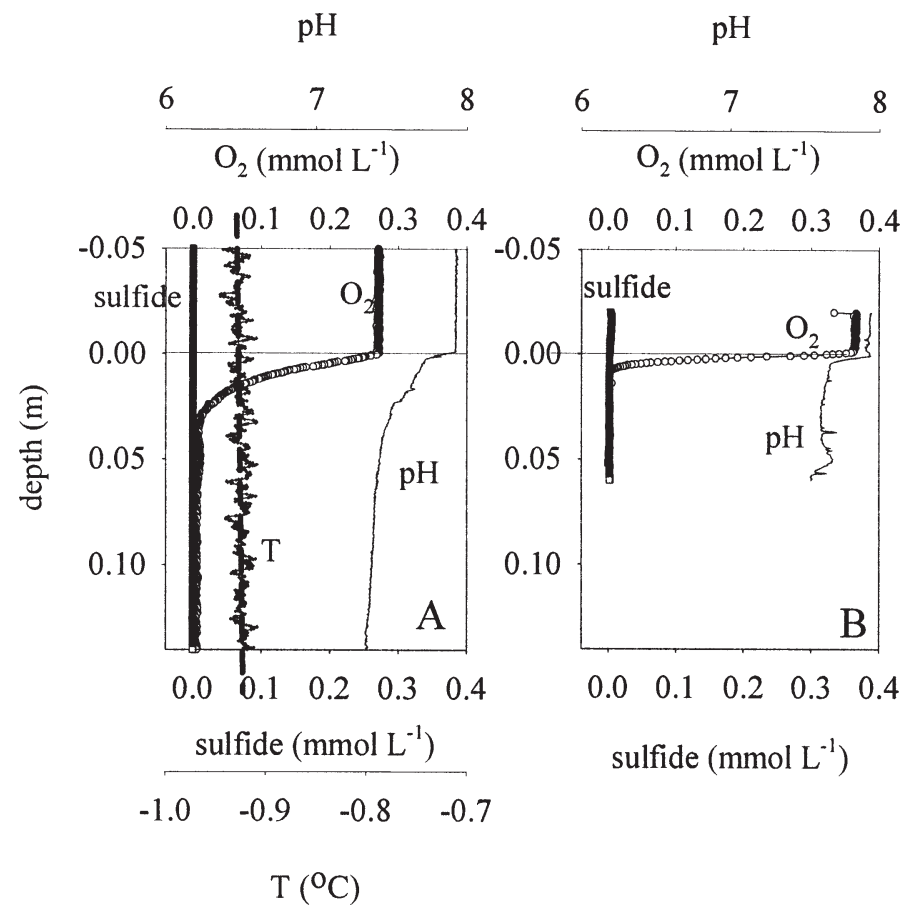

Fig. 11. (A) Microprofiles from the reference site, ca $50 \mathrm{~km}$ outside the mud volcano, measured in situ with the profiler on a free-falling lander. The temperature profile is level here because of the absence of a heat source. No sulfide was detected. (B) Microprofiles measured in retrieved cores.

tion $\mathrm{C}_{0}$ is constant, the concentration profile is obtained from:

$$
\mathrm{C}_{\mathrm{x}}=\mathrm{C}_{0} \mathrm{e}^{-\frac{v \mathrm{vx}}{\mathrm{D}_{\text {eff }}}}
$$

with $\mathrm{C}_{\mathrm{x}}$ the solute concentration at depth $\mathrm{x}, \mathrm{D}_{\text {eff }}$ the diffusion coefficient for the solute in the sediment, and $\mathrm{C}_{0}$ the concentration at the source (in this case, the sulfide peak). The best fit was obtained at an upflow velocity between 0.5 and $0.6 \mathrm{~m} \mathrm{yr}^{-1}$ (Fig. 12B). The complete sulfide profiles were also calculated at different upflow velocities using a structured diffusion-advection-conversion model. The concentration at the peak is rather sensitive to the upflow velocity (Fig. 12A). When no upflow occurs, the sulfide concentration should reach $16 \mathrm{mmol} \mathrm{L}-1$ at $3 \mathrm{~cm}$ depth and should not decrease with depth. At an upflow velocity of between 0.3 and $0.5 \mathrm{~m} \mathrm{yr}^{-1}$ the measured peak height of $4 \mathrm{mmol} \mathrm{L}^{-1}$ is obtained. The best estimation for upflow velocities in Beggiatoa mats, based on the analyses of the sulfide profiles, is 0.3 $0.6 \mathrm{~m} \mathrm{yr}^{-1}$. At higher flow velocities, sulfide would disappear from the sediments. This range is at the lower end of the flow velocities modeled from temperature profiles obtained with a 3-m temperature lance (Table 2).

The sulfide profile allows for calculation of the upflow velocity in the Beggiatoa mats, but not in the center, where sulfide is absent. Here we calculated upward pore-water flow from the oxygen profiles in the uppermost sediment layer and the temperature profiles over the top $3 \mathrm{~m}$. The
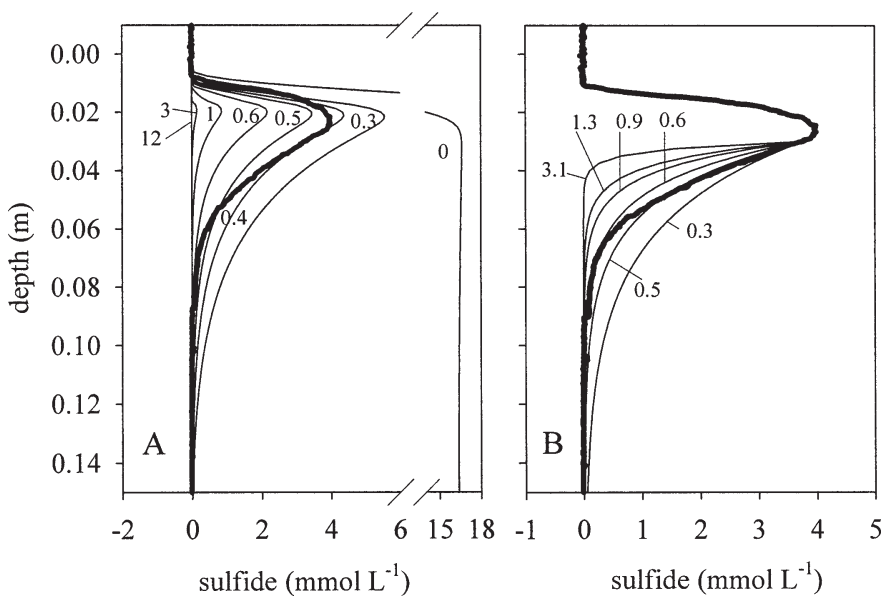

Fig. 12. Modeled sulfide microprofiles fitted to those measured in Beggiatoa mats by the upflow velocity (indicated by

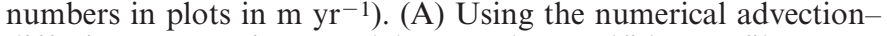
diffusion-conversion model, complete sulfide profiles were calculated, resulting in a best fit to the peak height at a flow of $0.4 \mathrm{~m} \mathrm{yr}^{-1}$. (B) With Eq. 4, a best fit was obtained at a flow of between 0.5 and $0.6 \mathrm{~m} \mathrm{yr}^{-1}$.

volumetric oxygen consumption rate by aerobic methane oxidation was $2.7 \times 10^{-6} \mathrm{~mol} \mathrm{~m}^{-3} \mathrm{~s}^{-1}$ at $1 \mathrm{mmol} \mathrm{L}^{-1}$ methane, determined on freshly collected sediments (Niemann 2005). We used this conversion rate to fit the in situ measured oxygen profiles by adjusting the upflow velocity with the diffusion-advection-conversion model, assuming methane to be the sole e-donor for oxygen consumption and assuming first-order kinetics for aerobic methane oxidation (Krüger pers. comm.). As the in situ methane concentration is unknown, we calculated the methane profiles assuming 40,80 , or $170 \mathrm{mmol} \mathrm{L}^{-1}$ of methane at $15 \mathrm{~cm}$ in depth. Reasonable fits could be obtained with upflow velocities of $1.6 \mathrm{~m} \mathrm{yr}^{-1}\left(170 \mathrm{mmol} \mathrm{L}^{-1}\right)$, $3.2 \mathrm{~m} \mathrm{yr}^{-1}\left(80 \mathrm{mmol} \mathrm{L}^{-1}\right)$, or $6.4 \mathrm{~m} \mathrm{yr}^{-1}\left(40 \mathrm{mmol} \mathrm{L}^{-1}\right)$. Since the actual methane concentration is most likely between 40 and $80 \mathrm{mmol} \mathrm{L}^{-1}$ (Wallmann et al. 1997), the best estimate for upflow velocities in the center is 3 to $6 \mathrm{~m} \mathrm{yr}^{-1}$. Although two strains of aerobic methane oxidizers dominated the microbial community (Niemann 2005; Lösekann unpubl. data), the assumption that methane was the only oxygen-consuming process is uncertain, as we have no data on other reducing substances in the sediments, such as ammonium and ferric iron. Nevertheless, this estimate matched the fluid flow calculated from 3-m temperature profiles quite well (Table 2).

From the one-dimensional evaluation of the temperature profiles in the top $3 \mathrm{~m}$ we obtained a heterogeneous impression of the upflow velocities in the volcano. Obviously, the absolute temperature in the top $3 \mathrm{~m}$ increased drastically in the transect Pogonophora-Beggiatoa-Central area (Fig. 2), which might be indicative of higher pore-water upflow in the center. However, only the curvature of the temperature allows quantification of upflow, and this also increased from the periphery toward the center. The estimated upflow velocities in the center ranged between 1.3 and $5.3 \mathrm{~m} \mathrm{yr}^{-1}$ (average, $2.5 \mathrm{~m} \mathrm{yr}^{-1}$ ), 
two values in a Beggiatoa mat were 0.6 and $1 \mathrm{~m} \mathrm{yr}^{-1}$, and upflow in two Pogonophora sites was $0.4 \mathrm{~m} \mathrm{yr}^{-1}$. Other values ranged between 0.4 and $1.5 \mathrm{~m} \mathrm{yr}^{-1}$, but their position could not be assigned with certainty to a habitat. The one-dimensional analysis of temperature profiles has the uncertainty that other effects can result in nonlinear temperature gradients (i.e., mass wasting or transient temperature effects), and the accuracy is on the order of $0.2 \mathrm{~m} \mathrm{yr}^{-1}$. However, both the in situ oxygen and sulfide profiles and the in situ temperature profiles are in agreement with a moderate upflow velocity through the Beggiatoa mats and a much higher upflow velocity through the center sediments. Although we cannot exclude an effect of mud flow and deposition of temperature profiles, the observed temperature curves, the microsensor data, and the distribution of biological communities appear to be best explained by a radial decrease of fluid flow from the center to the periphery of the HMMV.

When this tentative pore-water flow stops, as occurs after sampling, the sulfide concentration under Beggiatoa mats must gradually increase below the zone of AOM, and the profiles will level off. Assuming the AOM zone was an infinite source of sulfide with a fixed concentration and assuming sediments below an initially sulfide-free and infinite medium with no sulfide-consuming or -producing activities, then the transient sulfide profiles $\left(\mathrm{C}_{\mathrm{t}, \mathrm{x}}\right)$ in this medium are described by (Crank 1975)

$$
\mathrm{C}_{\mathrm{t}, \mathrm{x}}=-\mathrm{C}_{\mathrm{AOM}} \operatorname{Erf}\left(\frac{\mathrm{x}}{\sqrt{\mathrm{D}_{\mathrm{eff}} \mathrm{t}}}\right)+\mathrm{C}_{\mathrm{AOM}}
$$

where $\mathrm{C}_{\mathrm{AOM}}$ is the sulfide concentration at the peak of AOM activity and $\mathrm{x}$ is the depth in the sediment. Applying this formula on the measured profiles showed that the sulfide decrease below the peak will remain for months, even in the absence of a sulfide-consuming process or upward advection. Unlike the sulfide profile, the oxygen profile can fully re-equilibrate in the $12 \mathrm{~h}$ between sampling and measurement, as the diffusive distance is much shorter.

A pore-water upflow will decrease the oxygen influx and increase the sulfide flux in upward direction. Therefore, the values in Table 3 may have to be corrected to obtain realistic budgets. As the oxygen concentration at the surface of the Beggiatoa mats was ca $0.25 \mathrm{mmol} \mathrm{L}^{-1}$, an upward pore-water velocity of $0.5 \mathrm{~m} \mathrm{yr}^{-1}(1.5 \times$ $10^{-8} \mathrm{~m} \mathrm{~s}^{-1}$ ) would lead to an advectional flux of $0.38 \times$ $10^{-8} \mathrm{~mol} \mathrm{~m}^{-2} \mathrm{~s}^{-1}$. Thus, in the Beggiatoa-covered sediments, the advectional oxygen outflow was only $3 \%$ of the diffusional oxygen influx. At the point at which the upward-directed sulfide flux was calculated, the sulfide concentration was ca $1.5 \mathrm{mmol} \mathrm{L}^{-1}$, leading to an advectional flux upward of $2.3 \times 10^{-8} \mathrm{~mol} \mathrm{~m}^{-2} \mathrm{~s}^{-1}$. Advection increases the total sulfide upflux, $\mathrm{J}_{\mathrm{D}}+\mathrm{J}_{\mathrm{adv}}$, from $2.16 \times$ $10^{-7} \mathrm{~mol} \mathrm{~m}^{-2} \mathrm{~s}^{-1}$ to $2.39 \times 10^{-7} \mathrm{~mol} \mathrm{~m}^{-2} \mathrm{~s}^{-1}$; the downward flux below the peak would be reduced from $0.44 \times 10^{-8} \mathrm{~mol} \mathrm{~m}^{-2} \mathrm{~s}^{-1}$ to ca $0.2 \times 10^{-8} \mathrm{~mol} \mathrm{~m}^{-2} \mathrm{~s}^{-1}$. Thus, in Beggiatoa mats, advection leads to a minor correction of the budgets calculated with diffusional fluxes. The estimated pore-water flow of $6 \mathrm{~m} \mathrm{yr}^{-1}(2 \times$ $10^{-7} \mathrm{~m} \mathrm{~s}^{-1}$ ) in the central area significantly reduced the oxygen uptake to $30 \%$ of the diffusional influx. In Beggiatoa mats, the advectional fluxes hardly influence the budgets calculated from the diffusional fluxes, but for the central area, a correction for the advectional oxygen flux is needed.

The estimated pore-water flow velocities of less than $6 \mathrm{~m} \mathrm{yr}^{-1}\left(2 \times 10^{-7} \mathrm{~m} \mathrm{~s}^{-1}\right)$ will not lead to suspension of the extremely fine, almost-liquid sediments of the HMMV. Complete settling of suspended sediments over a depth of $10 \mathrm{~cm}$ occurred within 3-6 h; thus, the settling velocity of the finest particles is higher than $220 \mathrm{~m} \mathrm{yr}^{-1}(7 \times$ $10^{-6} \mathrm{~m} \mathrm{~s}^{-1}$ ). Therefore, pore-water upflow, in the order of magnitude as estimated, is possible without suspending the sediment. The budget calculations show that such low flow velocities can be relevant for sediment-water exchange and for microbial activities in the sediment.

Microzonation of biogeochemical processes - Center: The diffusive oxygen fluxes in the central area were very high, which might indicate high microbial activity. We found no evidence of kinetic limitations (e.g., by extreme $\mathrm{pH}$ or temperature); therefore, we further considered mass transfer limitations as the factor controlling AOM. The oxygen uptake was most likely driven by aerobic oxidation of methane in the surface sediments. The sulfide levels were very low, indicating that $\mathrm{AOM}$ was not significant in the central area. It is most likely that sulfate limits AOM in these sediments, simply because the upward-flowing sulfate-free pore water drives the sulfate out of the sediment faster than it can diffuse in. The ex situ sulfate profiles from the central area and the Beggiatoa mats, presented in Fig. 4, are certainly subjected to mixing with the water column during retrieval. In reality, sulfate will penetrate much less than the observed $5 \mathrm{~cm}$. Unfortunately, no sulfate microsensor suitable for seawater studies is available. Under the assumption that no sulfate conversion occurs in these sediments, and the assumption that upflow velocity is indeed 3-6 $\mathrm{m} \mathrm{yr}^{-1}$, sulfate penetration can be estimated to be very limited. Using Eq. 5, and using a surface concentration of $28 \mathrm{mmol} \mathrm{L}-1$, a $\mathrm{D}_{0}$ of $0.5 \times 10^{-9} \mathrm{~m}^{2} \mathrm{~s}^{-1}\left(\mathrm{D}_{\text {eff }} 0.18 \times\right.$ $\left.10^{-9} \mathrm{~m}^{2} \mathrm{~s}^{-1}\right)$, and an upflow velocity of $6 \mathrm{~m} \mathrm{yr}^{-1}$, the sulfate concentration will decrease to below $1 \mathrm{mmol} \mathrm{L}^{-1}$ in the top first millimeter, and sub- $\mu \mathrm{mol} \mathrm{L}-1$ concentrations are reached below $5 \mathrm{~mm}$ in depth (Fig. 4). As a result of the relatively high pore-water flow, sulfate supply to anoxic zones is insufficient for AOM in the center.

Beggiatoa and gray mats: Under the Beggiatoa mats, a clear sulfide peak indicates an AOM hot spot. This microenvironment is characterized by a concentration of 4 $5 \mathrm{mmol} \mathrm{L}-1$ sulfide and a $\mathrm{pH}$ of ca 7.5. The zone in which sulfide disappears has a $\mathrm{pH}$ close to 7.8 , and no oxygen could be detected. The areal sulfide production (and thus AOM rate) is very high and is limited by sulfate transport. As high sulfate conversions occur in these sediments, Eq. 5 cannot be used. The diffusional sulfate flux from the water column to the AOM hot spot can maximally be $2 \times$ $10^{-7} \mathrm{~mol} \mathrm{~m}^{-2} \mathrm{~s}^{-1}\left(\mathrm{D}_{0}=0.5 \times 10^{-9} \mathrm{~m}^{2} \mathrm{~s}^{-1}, \mathrm{dC}=\right.$ $\left.28 \mathrm{mmol} \mathrm{L}^{-1}, \mathrm{dx}=0.025 \mathrm{~m}\right)$. This is slightly below the calculated sulfide production (Table 3). However, sulfate 
reduction must be additionally fueled by sulfate or oxidized sulfur intermediates produced by Beggiatoa in the anoxic zone. Actually, as all sulfide is oxidized below $1 \mathrm{~cm}$ in depth, the sulfur cycle inside the sediment may be closed. Thus, the diffusive distance for sulfate (or another oxidized sulfur species that can fuel sulfate reduction) between the site of production and consumption will be much less than $2.5 \mathrm{~cm}$. Further studies should be carried out to investigate the cycling of sulfur intermediates between Beggiatoa and AOM bacteria.

Most interestingly, the $\mathrm{pH}$ seems not to be influenced by $\mathrm{AOM}$ as the main microbial processes, as the $\mathrm{pH}$ profiles in the HMMV resemble those in sediments without AOM. This is contrary to our expectation, since AOM, for which the net process is given by

$$
\mathrm{CH}_{4}+\mathrm{SO}_{4}^{2-} \rightarrow \mathrm{HCO}_{3}^{-}+\mathrm{HS}^{-}
$$

should lead to a pH increase (Zeebe et al. 2001). In another site in the Eckenförder Bucht (near Kiel, Germany) with methane-rich sediments, we also observed a gradual $\mathrm{pH}$ decrease in the AOM zone and no increase (data not shown). It is possible that the $\mathrm{pH}$ increase by AOM is balanced by a $\mathrm{pH}$ decrease resulting from calcium carbonate precipitation. Such precipitations are often found in methane-rich sediments and are thought to originate from AOM-related oversaturation in carbonate and alkaline pH shifts (Michaelis et al. 2002; Boetius and Suess 2004) formed at moderate $\left(20-60 \mathrm{~cm} \mathrm{yr}^{-1}\right)$ upflow velocities (Luff et al. 2004). Unlike what we observed in other seeps, we did not find carbonate crusts at the HMMV, nor did we find $\mathrm{pH}$ increases in zones with high AOM rates. The effects of AOM on the carbonate system and crust formations need further study.

The net equation for aerobic SO to sulfate is

$$
\mathrm{HS}^{-}+2 \mathrm{O}_{2} \rightarrow \mathrm{SO}_{4}^{2^{-}}+\mathrm{H}^{+}
$$

This process leads to a strong $\mathrm{pH}$ decrease. In the gray mats, the $\mathrm{pH}$ decreased where sulfide overlapped with oxygen. Combined with the close stoichiometry of the sulfide and oxygen fluxes, this is good evidence that in gray mats, aerobic SO is dominant. The microbial process of anaerobic SO to sulfate, coupled with nitrate conversion to ammonium, is given by

$$
\mathrm{HS}^{-}+\mathrm{NO}_{3}^{-}+\mathrm{H}_{2} \mathrm{O} \rightarrow \mathrm{SO}_{4}^{2-}+\mathrm{NH}_{4}^{+}+\mathrm{OH}^{-}
$$

The sulfidic zone under the Beggiatoa mat was separated from the oxic zone; thus, sulfide was oxidized anaerobically and this did not lead to a $\mathrm{pH}$ change. That aerobic SO leads to proton production and local $\mathrm{pH}$ decrease has often been observed with microsensors (Revsbech et al. 1983; Kühl and Jørgensen 1992; Wieland and Kühl 2000). Anaerobic $\mathrm{SO}$, using nitrate as electron-acceptor, involves the conversion of a weak base into another weak base and a $\mathrm{pH}$-neutral compound into another $\mathrm{pH}$-neutral compound. It could lead to a small $\mathrm{pH}$ increase if the oxidation is completely to sulfate. Whether such a $\mathrm{pH}$ change can be detected on a microscale has not yet been experimentally verified in gradient systems.
In the Beggiatoa mats, aerobic SO cannot be significant, as the sulfide flux is at least twice the oxygen flux. Complete aerobic SO would result in oxygen fluxes that are twice the sulfide fluxes. Moreover, an 8-h experimental decrease in seawater oxygen did not change the sulfide profiles and fluxes in the upper layer of the sediment. Beggiatoa is well known to be able to oxidize sulfide with nitrate, with sulfate or sulfur and ammonium as product(s) (Vargas and Strohl 1985; McHatton et al. 1996). The absence of $\mathrm{N}_{2} \mathrm{O}$ development upon exposure to acetylene confirms that ammonium, and not $\mathrm{N}_{2}$, is formed in the Beggiatoa mats. The nitrate concentration in the seawater was ca $15 \mu \mathrm{mol} \mathrm{L}-1$, which is far too low to allow for diffusion of nitrate into the sediments at a rate stoichiometric to the upward sulfide flux. An alternative transfer mechanism is active nitrate transport in the vacuoles of the gliding bacteria, the mats of which must be ventilated by seawater (Gundersen et al. 1992). Indeed, a strong accumulation of nitrate was observed in the top of the HMMV sediments covered with Beggiatoa mats. As in Beggiatoa mats, sulfide and methane are oxidized anaerobically; two anaerobic oxidation processes prevent emission of most sulfide and methane to the seawater. In future visits to the HMMV, the nitrate uptake will be quantified and compared to AOM rates.

Also in the gray mats, large nitrate-storing bacteria were observed; nevertheless, the overlapping oxygen and sulfide profiles indicate that nitrate is not an important e-acceptor. The large diversity of giant sulfide oxidizers near the seeps may be related to the dynamics of the physico-chemical conditions. The patchy gray mats occurred at the parts of the HMMV apparently affected by recent mud volcanism, according to our visual observations. They may represent pioneer communities, whereas the white Beggiatoa mats, with only one morphotype, occur in the more stable settings. In particular, gray mats harbored large, spherical cells with sulfur inclusions resembling Thiomargarita cells (Schulz et al. 1999). These nonmotile organisms depend on either temporal exposure to sulfide and nitrate or on a gradient system in which both overlap. Since sulfide diffused up to the oxic zone, overlap of sulfide with nitrate is very likely. Up until now, these giant bacteria are found at the Namibian coast, and a relative was found in the Gulf of Mexico (Kalanetra et al. 2003). It is mysterious how these fast-settling nonmotile bacteria have dispersed globally. However, the known populations apparently are not identical: the Namibian cells form strains of ca $300 \mu \mathrm{m}$ in diameter; those found in the Gulf of Mexico occur in sarcina-like clusters of almost $1 \mathrm{~mm}$, while those in the HMMV are single cells of ca $125 \mu \mathrm{m}$.

In sediments with Pogonophora worms, oxygen and sulfate penetrated deep as a result of ventilation by the worms. The downward ventilation flow must be compensated for by an equal upward water flow, allowing for transport of reduced substances toward the sediment's surface. In situ, in the top $10 \mathrm{~cm}$ of the sediment, sulfide and oxygen overlapped. The e-acceptors oxygen and sulfate are pumped downward by the ventilating worms, and sulfide is pumped upward. The tubes leak both sulfide and oxygen, as was shown by the in situ profiles. Here 
a significant part of methane oxidation and $\mathrm{SO}$ is probably aerobic. No sulfide was found in the top layer of retrieved sediments, in which the worms had stopped ventilating. The tube worms probably did not survive retrieval, and ventilation of tubes stopped - thus, the strongly reduced oxygen penetration in retrieved sediments. As well, it is likely that methane is transported to the oxic zone by the activity of the worms; thus, both aerobic methane oxidation and SO may occur in Pogonophora-infested sediments. It was found that two species of Pogonophora are present in the HMMV, most likely harboring methaneoxidizing bacteria and possibly also sulfide-oxidizing ones (Pimenov et al. 2000).

The pore-water upflow rates in the central area are roughly 3-6 m yr-1 , and in the more peripheral Beggiatoa mats, they are likely $0.3-0.6 \mathrm{~m} \mathrm{yr}^{-1}$. At these velocities, the pore-water upflow limits the penetration of e-acceptors into the sediment. At the center, methane oxidation is likely limited by both diffusional oxygen and sulfate penetration, and some methane may leak out of the sediment. Outside the central zone, the pore-water upflow is slower, allowing diffusional penetration of sulfate. Here AOM communities develop, producing sulfide, which is then anaerobically oxidized by Beggiatoa. Sulfate limitation will determine the depth at which AOM occurs, which is below the Beggiatoa mats at $2-3 \mathrm{~cm}$ in depth. Finally, in the outer areas of the volcano, upflow is even lower, and the transport of methane to electron acceptors is facilitated by ventilating Pogonophora worms. As sulfate is efficiently transported deep into the sediments, AOM can occur at great depths. Such transport seems an optimal adaptation for the worms to effectively compete for e-donors. It is likely that Pogonophora can only live in sediments with very low net upward flow, since their tubes will form preferred flow channels. The continuous downward pumping of oxygenrich water against an upward water flow would be energy demanding, and the worms would suffocate. In the areas with pore-water upflow velocities that are sufficiently moderate to allow AOM, Beggiatoa can dominate. Both communities appear to populate a similarly sized area at the HMMV today, but an interesting question remains with regard to what determines the radiation and succession of these potentially competing chemosynthetic communities over time at newly formed mud volcano surfaces.

The differences between the three habitats can be explained by sulfate availability and thus by mass transfer limitation by pore-water flow through a stagnant sediment. As an alternative hypothesis, kinetic limitations could be considered, but conditions in the center $(\mathrm{T}, \mathrm{pH}$, and methane availability) seem suitable for AOM. Another possible scenario is that the sediments in the center are recently disturbed by active volcanism and have not yet been re-colonized by the slow-growing AOM bacteria. Recent disturbance could also cause nonlinear $\mathrm{T}$ profiles. The sediments below the Beggiatoa mats would have been disturbed longer ago, thus allowing sufficient time for colonization by AOM, and the surrounding other area would have had sufficient time after its formation to be colonized by even slower growing Pogonophora. Such a scenario implicates a sediment's motion along a conveyor belt from the central area outward, where sediments should accumulate. We saw no signs of recent disturbance by extrusion in the center, which was flat and without clear features. No accumulation of sediments in or around the volcano area occurs. Although AOM communities grow slowly (Girguis et al. 2005), even a cell-division every 3 months would allow colonization within 3-5 yr, as the amount of AOM biomarkers was ca $1 \%$ of that under the Beggiatoa mats (Niemann 2005). In this scenario, horizontal sediment velocities would be on the order of $100 \mathrm{~m} \mathrm{yr}^{-1}$. Furthermore, this hypothesis does not explain the difference in Pogonophora and Beggiatoa habitats. Further field work is necessary to test these different hypotheses and their effects on habitat structure.

Comparison to fluid flow at other cold seep systemsPore-water flow velocities estimated in this study from oxygen and sulfide microprofiles were ca $0.3-0.6 \mathrm{~m} \mathrm{yr}^{-1}$ in Beggiatoa mats, falling in the higher range of previously reported values (Wallmann et al. 1997; Torres et al. 2002, 2004; Tryon et al. 2002; Luff and Wallmann 2003). The highest flow velocities at the HMMV were estimated to reach $6 \mathrm{~m} \mathrm{yr}^{-1}$. Flow velocities have been estimated using transport-conversion models and have been directly measured. Indirect estimates from pore-water analyses on retrieved cores generally lead to lower values. By fitting pore-water data to a conversion diffusion model, flow velocities were obtained of $0.04 \mathrm{~m} \mathrm{yr}^{-1}$ in the Kazan Mud Volcano (Haese et al. 2003), $0.1 \mathrm{~m} \mathrm{yr}^{-1}$ in sediments on Hydrate Ridge (Luff and Wallmann 2003), $0.3-1 \mathrm{~m} \mathrm{yr}^{-1}$ in sediments on Hydrate Ridge (Torres et al. 2002), and $3.5 \mathrm{~m} \mathrm{yr}^{-1}$ in sediments from a cold vent on the Aleutian subduction zone (Wallmann et al. 1997). At Hydrate Ridge, from a temperature profile and a one-dimensional heat transport model, a flow of $0.1 \mathrm{~m} \mathrm{yr}^{-1}$ was obtained (Torres et al. 2004). Direct measurements seem to give higher values than those obtained from models. Using a so-called 'benthic barrel' that funnels upward flow to a thermistor flow meter, flow velocities of $30-1,000 \mathrm{~m} \mathrm{yr}^{-1}$ were measured on Hydrate Ridge (Linke et al. 1994). With a conceptually similar device that measures flow by injecting dye in the funnel opening, flow velocities through Beggiatoa mats on Hydrate Ridge of $0.2-2.5 \mathrm{~m} \mathrm{yr}^{-1}$ have been determined (Tryon et al. 2002). An important reason for the variation in the values is the real variability of the flow velocities at small scales per site (Torres et al. 2002) and between sites. However, differences measuring orders of magnitude from similar sites may indicate artifacts in measurements or wrong assumptions for the modeling. Fitting pore water from retrieved cores will lead to underestimation of upflow when 'smearing' of the profiles has occurred, even when the smearing was moderate. This is illustrated with our sulfate profiles measured in cores from the center (Fig. 4). The best fit of these profiles with the simple transport model (Eq. 5) is with a flow velocity of $0.3 \mathrm{~m} \mathrm{yr}^{-1}$. This underestimates a more probable value with one order of magnitude. When calculating the sulfate profiles with the transport-conversion model, we obtained a much steeper profile than measured (Fig. 4). The sulfate profiles measured on retrieved sediments are not possible 
with the AOM rates found under the Beggiatoa mats, even at a flow velocity of zero in sediments (not shown). We conclude that our sulfate profiles from retrieved sediments do not represent the in situ situation, because as a result of degassing during retrieval, additional sulfate from the bottom water has penetrated into the top $5-10 \mathrm{~cm}$. Our measured sulfate profiles do not relate to the differences in microbiology between the center and the Beggiatoa mats, nor do they explain the spatial distribution of AOM in the Beggiatoa mats. Generally such profiles should be used with caution for estimating pore-water flow in gas-bearing sediments.

Cold seep ecosystems, like subsurface gas hydrate deposits, gas ebullition sites, pockmarks, and mud volcanoes, are characterized by vertical fluid flow transporting methane and other hydrocarbons from deep reservoirs to the seafloor. The importance of pore-water flow for the supply of methane is well recognized. However, we argue that such high flow velocities control the supply of electron acceptors to the microbial communities in the sediments to the point that methane-oxidizing communities are completely restricted to small sediment horizons of a millimeter scale. This mechanism has so far been ignored as an important factor controlling the distribution of microbial communities. The most likely scenario explaining the concentric distribution of microbial habitats at HMMV is the change in the upflow velocity of methane-rich and sulfate-depleted pore water. Our study shows that the quantitative investigation of mass transfer phenomena, especially with regard to the availability of electron acceptors, is critical for an understanding of the ecology, diversity, and biogeochemistry of mud volcanoes and other types of cold seep ecosystems.

\section{References}

Berg, P., N. Risgahard-Pedersen, and S. RysgaArd. 1998. Interpretation of measured concentration profiles in sediment pore water. Limnol. Oceanogr. 43: 1500-1510.

Boetius, A., And E. Suess. 2004. Hydrate Ridge: A natural laboratory for the study of microbial life fuelled by methane from near-surface gas hydrates. Chem. Geol. 205: 291-310.

- AND OTHERs. 2000. A marine microbial consortium apparently mediating anaerobic oxidation of methane. Nature 407: 623-626.

Boudreau, B. 1997. Diagenetic models and their implementation. Springer.

Braman, R. S., And S. A. Hendrix. 1989. Nanogram nitrite and nitrate determination in environmental and biological-materials by Vanadium(III) reduction with chemi-luminescence detection. Anal. Chem. 61: 2715-2718.

BRedehoeft, J. D., AND I. S. PAPAdopulos. 1965. Rates of vertical groundwater movement estimated from the earth's thermal profile. Water Resources Res. 1: 325-328.

Crank, J. 1975. The mathematics of diffusion, 2nd ed. Oxford Univ. Press.

De Beer, D., A. Glud, E. Epping, and M. Kühl. 1997a. A fast responding $\mathrm{CO}_{2}$ micro-electrode for profiling sediments, microbial mats and biofilms. Limnol. Oceanogr. 42: $1590-1600$

— AND M. KÜHL. 2000. Interfacial processes, gradients and metabolic activity in microbial mats and biofilms, p. 374-394. In B. Boudreau and B. B. Jørgensen [eds.], The benthic boundary layer. Oxford Univ. Press.
-, A. Schramm, C. M. Santegoeds, and M. Kühl. 1997b. A nitrite microsensor for profiling environmental biofilms. Appl. Environ. Microbiol. 63: 973-977.

Edy, C., AND H. Bisquay. 2004. Microbathymetry on ROV 'Victor 6000', p. 158-163. In M. Klages, J. Thiede and J. P. Foucher [eds.], The expedition ARKTIS XIX/3 of the research vessel Polarstern in 2003. Berichte zur Polar- und Meeresforschung. Alfred Wegener Institut für Polar- und Meeresforschung.

Gieseke, A., L. Buerrum, M. Wagner, and R. Amann. 2003. Structure and activity of multiple nitrifying bacterial populations co-existing in a biofilm. Environ. Microbiol. 5: 355369.

Girguis, P. R., A. E. Cozen, And E. F. Delong. 2005. Growth and population dynamics of anaerobic methane-oxidizing archaea and sulfate-reducing bacteria in a continuous-flow bioreactor. Appl. Environ. Microbiol. 71: 3725-3733.

Glud, R. N., J. K. Gundersen, B. B. Jörgensen, N. P. Revsbech, AND H. D. Schulz. 1994. Diffusive and total oxygen uptake of deep-sea sediments in the eastern South Atlantic Ocean: In situ and laboratory measurements. Deep-Sea Res. I 41: $1767-1788$.

Gundersen, J. K., And B. B. Jørgensen. 1990. Microstructure of diffusive boundary layers and the oxygen uptake of the sea floor. Nature 345: 604-607.

E. Larsen, And H. W. Jannasch. 1992. Mats of giant sulphur bacteria on deep-sea sediments due to fluctuating hydrothermal flow. Nature 360: 454-455.

Haese, R. R., C. Meile, P. van Capellen, and G. J. de Lange. 2003. Carbon geochemistry of cold seeps: Methane fluxes and transformation in sediments from Kazan mud volcano, eastern Mediterranean Sea. Earth Planet. Sci. Lett. 212: 361-375.

Jerosch, K., A. G. Vincent, and M. Schlüter. 2004. Video mosaicking on Hakon Mosby Mud Vulcano, p. 215-220. In M. Klages, J. Thiede and J. P. Foucher [eds.], The expedition ARKTIS XIX/3 of the research vessel Polarstern in 2003. Berichte zur Polar- und Meeresforschung. Alfred Wegener Institut für Polar- und Meeresforschung.

Jeroschewski, P., C. Steukart, and M. Kühl. 1996. An amperometric microsensor for the determination of $\mathrm{H}_{2} \mathrm{~S}$ in aquatic environments. Anal. Chem. 68: 4351-4357.

Kalanetra, K. M., D. C. Nelson, and S. B. Joye. 2003. Evolutionary relationships of novel, vacuolate, sulfur-oxidizing bacteria from hydrothermal vents and cold seeps. Abstr. Gen. Meeting Am. Soc. Microbiol. 103-N: 362.

Kaul, N. J.-P., Foucher, and M. Heesemann. In press. Estimating mud expulsion rates from temperature measurements on Håkon Mosby Mud Volcano, SE Barents Sea. Mar. Geol.

KüHL, M., And B. B. Jørgensen. 1992. Microsensor measurements of sulfate reduction and sulfide oxidation in compact microbial communities of aerobic biofilms. Appl. Environ. Microbiol. 58: 1164-1174.

_, AND N. P. Revsbech. 2000. Biogeochemical microsensors for boundary layer studies, p. 180-210. In B. Boudreau and B. B. Jørgensen [eds.], The benthic boundary layer. Oxford Univ. Press.

Lein, A., P. Vogt, K. Crane, A. Egorov, and M. Ivanov. 1999. Chemical and isotopic evidence for the nature of the fluid in CH4-containing sediments of the Hakon Mosby Mud Volcano. Geo-Mar. Lett. 19: 76-83.

Li, Y.-H., AND S. Gregory. 1974. Diffusion of ions in sea water and deep-sea sediments. Geochim. Cosmochim. Acta 38: 703-714. 
Linke, P., E. Suess, M. Torres, V. Martens, W. D. Rugh, W. Ziebis, AND L. D. Kulm. 1994. In situ measurements of fluid flow from cold seeps at active continental margins. Deep-Sea Res. I 41: 721-739.

Luff, R., And K. Wallmann. 2003. Fluid flow, methane fluxes, carbonate precipitation and biogeochemical turnover in gas hydrate-bearing sediments at Hydrate Ridge, Cascadia Margin: Numerical modeling and mass balances. Geochim. Cosmochim. Acta 67: 3403-3421.

— - , AND G. Aloisi. 2004. Numerical modeling of carbonate crust formation at cold vent sites: Significance for fluid and methane budgets and chemosynthetic biological communities. Earth Planet. Sci. Lett. 221: 337-353.

Mchatton, S., J. P. Barry, H. W. Jannasch, and D. C. Nelson. 1996. High nitrate concentrations in vacuolate autotrophic marine Beggiatoa spp. Appl. Environ. Microbiol. 62: 954-958.

Michaelis, W., AND others. 2002. Microbial reefs in the Black Sea fueled by anaerobic oxidation of methane. Science 297: 1013-1015.

Millero, F. J., T. Plese, and M. Fernandez. 1988. The dissociation of hydrogen sulfide in seawater. Limnol. Oceanogr. 33: 269-274.

NiemanN, H. 2005. Rates and signatures of methane turnover in sediments of continental margins, p. 265. In Biology. Bremen Univ.

Orphan, V. J., C. H. House, K. U. Hinrichs, K. D. McKeegan, And E. F. Delong. 2002. Multiple archaeal groups mediate methane oxidation in anoxic cold seep sediments. Proc. Natl. Acad. Sci USA 99: 7663-7668.

Pearson, C. E. 1986. Numerical methods in engineering and science. Van Nostrand Reinhold.

Pimenov, N. V., A. S. Savvichev, I. I. Rusanov, A. Y. Lein, And M. V. Ivanov. 2000. Microbiological processes of the carbon and sulfur cycles at cold seeps of the North Atlantic. Microbiology 69: 709-720.

Reeburgh, W. S. 1967. An improved interstitial water sampler. Limnol. Oceanogr. 12: 163-170.

Revsbech, N. P., AND B. B. JøRGensen. 1986. Microelectrodes: Their use in microbial ecology. Adv. Microb. Ecol. 9: 293-352.

, T. H. BLACKBURN, AND Y. COHEN. 1983 Microelectrode studies of the photosynthesis and $\mathrm{O}_{2}, \mathrm{H}_{2} \mathrm{~S}$ and $\mathrm{pH}$ profiles of a microbial mat. Limnol. Oceanogr. 28: 1062-1074.

, L. P. Nielsen, P. B. Christensen, and J. Sorensen. 1988. A combined oxygen and nitrous oxide microsensor for denitrification studies. Appl. Environ. Microbiol. 45: 2245-2249.
— AND D. M. WARD. 1983. Oxygen microelectrode that is insensitive to medium chemical composition: Use in an acid microbial mat dominated by Cyanidium caldarum. Appl. Environ. Microbiol. 45: 755-759.

Sauter, E., M. Schlueter, And E. Seuss. 2001. Organic carbon flux and remineralization in surface sediments from the northern North Atlantic derived from pore-water oxygen microprofiles. Deep-Sea Res. 1: 529-553.

Schulz, H. N., T. Brinkhoff, T. G. Ferdelman, M. Hernandez Marine, A. Teske, and B. B. Jørgensen. 1999. Dense populations of a giant sulfur bacterium in Namibian shelf sediments. Science 284: 493-495.

— And B. B. Jørgensen. 2001. Big bacteria. Annu. Rev. Microbiol. 55: 105-137.

Torres, M., K. Wallmann, A. M. Trehu, G. Bohrmann, W. S. Borowski, AND H. TOMARU. 2004. Gas hydrate growth, methane transport, and chloride enrichment at the southern summit of Hydrate Ridge, Cascadia margin off Oregon. Earth Planet. Sci. Lett. 226: 225-241.

Torres, M. E., AND others. 2002. Fluid and chemical fluxes in and out of sediments hosting methane hydrate deposits on Hydrate Ridge, OR. I: Hydrological provinces. Earth Planet. Sci. Lett. 201: 525-540.

Tryon, M. D., K. M. Brown, And M. E. Torres. 2002. Fluid and chemical flux in and out of sediments hosting methane hydrate deposits on Hydrate Ridge, OR. II: Hydrological processes. Earth Planet. Sci. Lett. 201: 541-557.

Ullman, W. J., AND R. C. Aller. 1982. Diffusion coefficients in nearshore marine sediments. Limnol. Oceanogr. 27: 552-556.

Vargas, A., and W. R. Strohl. 1985. Utilization of nitrate by Beggiatoa alba. Arch. Microbiol. 142: 279-284.

WALlMANN, K., AND OTHERs. 1997. Quantifying fluid flow, solute mixing, and biogeochemical turnover at cold vents of the eastern Aleutian subduction zone. Geochim. Cosmochim. Acta 61: 5209-5219.

Wenzhöfer, F., And R. N. Glud. 2002. Benthic carbon mineralization in the Atlantic: A synthesis based on in situ data from the last decade. Deep-Sea Res. I 49: 1255-1279.

Wieland, A., AND M. KüHL. 2000. Short-term temperature effects on oxygen and sulfide cycling in a hypersaline cyanobacterial mat (Solar Lake, Egypt). Mar. Ecol. Prog. Ser. 196: 87-102.

Zeebe, R. E., A. Sanyal, J. D. Ortiz, and D. A. M. C. WolfGladrow. 2001. A theoretical study of the kinetics of the boric acid-borate equilibrium in seawater. Mar. Chem. 73: $113-124$.

Received: 16 April 2005 Amended: 16 December 2005 Accepted: 26 December 2005 